\title{
Feedback between dust particles and atmospheric processes over West Africa during dust episodes in March 2006 and June 2007
}

\author{
T. Stanelle ${ }^{1, *}$, B. Vogel ${ }^{1}$, H. Vogel ${ }^{1}$, D. Bäumer ${ }^{1,{ }^{* *}}$, and C. Kottmeier ${ }^{1}$ \\ ${ }^{1}$ Institute for Meteorology and Climate Research, Karlsruhe Institute of Technology, Karlsruhe, Germany \\ *now at: Institute for Atmospheric and Climate Science, Swiss Federal Institute of Technology (ETH), Zurich, Switzerland \\ ** now at: BASF, Ludwigshafen, Germany
}

Received: 22 January 2010 - Published in Atmos. Chem. Phys. Discuss.: 23 March 2010

Revised: 30 June 2010 - Accepted: 26 September 2010 - Published: 17 November 2010

\begin{abstract}
We used the comprehensive model system COSMO-ART to quantify the impact of mineral dust on the radiative fluxes, the temperature and the feedback between dust particles and their emissions. We simulated two dust storms over West Africa in March 2006 and in June 2007. Simulations with and without coupling of the actual dust concentration with the radiative fluxes and the thermodynamics were carried out for each case. The model results for the 2006 case were compared with observations of the AMMA campaign.
\end{abstract}

At the surface the shortwave radiative effect of mineral dust can be described by a linear relation between the changes in net surface radiation and the aerosol optical depth (AOD). For an AOD at $450 \mathrm{~nm}$ of 1 the average shortwave radiation reduction amounts $-140 \mathrm{~W} \mathrm{~m}^{-2}$ during noon. The longwave radiative effect of mineral dust is nonlinear, with an average increase of $+70 \mathrm{~W} \mathrm{~m}^{-2}$ for an AOD $(450 \mathrm{~nm})$ of 1. At the top of the atmosphere the effect of the dust layer with an AOD of 1 on radiative fluxes is not as significant as at the surface. It is slightly positive for the shortwave and approximately $26 \mathrm{~W} \mathrm{~m}^{-2}$ for the longwave radiation.

The height range and the extension of the dust layer determine the effect of dust particles on the $2 \mathrm{~m}$ temperature. When the dust layer is attached to the surface and lasts for several days it leads to an increase of the surface temperature even during daytime. In case of an elevated dust layer there is a decrease in $2 \mathrm{~m}$ temperature of up to $4 \mathrm{~K}$ during noon.

It is shown, that the temperature changes caused by mineral dust may result in horizontal temperature gradients which also modify near surface winds. Since surface wind

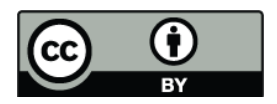

Correspondence to: B. Vogel

(bernhard.vogel@kit.edu) thresholds decide the uptake of dust from the surface, a feedback on total emission fluxes is established. The coupled model provides an increase in the total emission fluxes of dust particles by about $16 \%$ during the dust storm in March 2006 and 25\% during the dust episode in June 2007.

\section{Introduction}

Mineral dust is one of the most important sources of aerosol mass for the atmosphere (Seinfeld and Pandis, 1998). Dust is involved in many important processes in Earth's climate system. An important process is the influence of dust particles on the atmospheric radiation budget. It is influenced directly by absorption and scattering of incoming solar radiation, and absorption and re-emission of outgoing longwave radiation. Mineral dust particles have an impact on cloud formation and therefore on the indirect aerosol effect (IPCC, 2007). While the scattering of solar radiation and the indirect aerosol effect tend to cool the atmosphere, the absorption of radiation by aerosols leads to a warming of the atmosphere and to a suppression of cloud formation (semi-direct effect) (e.g., Twomey et al., 1984; Albrecht, 1989; Charlson et al., 1992; Schwartz, 1996; Rosenfeld, 2000; Ackermann et al., 2000; Chameides et al., 2002; Nenes et al., 2002; Cook and Highwood, 2004; Johnson et al., 2004; Helmert et al., 2007). Estimates of the global radiative forcing of mineral dust vary between $-0.56 \mathrm{~W} \mathrm{~m}^{-2}$ and $+0.1 \mathrm{~W} \mathrm{~m}^{-2}$ (IPCC, 2007) which shows its relatively large cooling effect but also the high uncertainty.

The uncertainty is largely determined by insufficiently quantified processes. Many studies have investigated the direct radiative forcing of mineral dust particles on the global

Published by Copernicus Publications on behalf of the European Geosciences Union. 
scale (e.g., Tegen et al., 1996; Miller et al., 2004; Perlwitz et al., 2001; Yoshioka et al., 2007). But these studies were done with a coarse spatial resolution of soil data and meteorological fields. This creates large uncertainties (Zender et al., 2003).

For numerical weather prediction models Kischa et al. (2003) and Haywood et al. (2005) suggest that a correct treatment of mineral dust and its radiative effects would improve the representation of the radiation budget and the accuracy of the weather prediction itself. In addition Chaboureau et al. (2007) point out that the use of prognostic dust aerosol, instead of climatology, improved the simulation of convective activity in West Africa. The forecast of the central dynamical feature in this region, the African Easterly Jet is enhanced by the use of a realistic distribution of mineral dust aerosols in the model (Tompkins et al., 2005).

Recently, regional dust transport models have been developed and coupled to numerical weather prediction models (e.g., Nickovic et al., 2001; Tegen et al., 2006; Heinold et al., 2007; Tulet et al., 2008). For modelling the influence of dust particles on the radiation budget, the emission and transport of dust particles must be calculated. In addition the refractive indices of the dust particles have to be known. Its real and imaginary parts represent the reflective and absorptive properties, respectively. The refractive indices depend considerably on the mineralogical composition. The mineralogical composition of dust particles has a strong dependence on the source region (Formenti et al., 2008; Petzold et al., 2009).

Helmert et al. (2007) investigated the sensitivity of radiative forcing and its impact on atmospheric dynamics and dust optical properties with the regional dust model LMMUSCAT-DES. They show that the large variability in radiative properties due to different mixtures of clay aggregates found in Saharan dust can lead to high differences in the radiation budget. For a quantification of the effects of mineral dust on the radiation budget they used the mean radiative efficiency. The radiative efficiency is the radiative forcing produced by an AOD of 1 and is a function of height. They found a mean shortwave radiative efficiency of $-196 \mathrm{~W} \mathrm{~m}^{-2}$ for prevailingly reflecting dust particles and $-220 \mathrm{~W} \mathrm{~m}^{-2}$ for prevailingly absorbing dust particles at the surface in the southern Sahara. The longwave radiative efficiency was determined to be about $60 \mathrm{~W} \mathrm{~m}^{-2}$ and $64 \mathrm{~W} \mathrm{~m}^{-2}$, respectively for the prevailingly absorbing dust particles. Milton et al. (2008) found a reduction in net downward shortwave flux at the surface with a maximum of $-200 \mathrm{~W} \mathrm{~m}^{-2}$ for a dust storm that occurred over West Africa in March 2006.

Tulet et al. (2008) and Mallet et al. (2009) used the standard formulation of absorption and reemission of longwave radiation for aerosols from the ECMWF model in the MESO$\mathrm{NH}$ model. They added a fraction of the $550 \mathrm{~nm}$ optical depth to the longwave optical depth of $\mathrm{CO}_{2}$ and $\mathrm{H}_{2} \mathrm{O}$. This fraction is constant for each aerosol type (ECMWF, 2004). This assumption results in inaccuracies in the calculations of the longwave radiative effect, however (Grini et al., 2006).
Changes in the radiative fluxes have an influence on surface and air temperature. Mallet et al. (2009) found a reduction of surface temperature of up to $4 \mathrm{~K}$ over regions where high AODs occur. For the initial stage of a dust storm in March 2005, Tegen et al. (2006) found a decrease in maximum daytime temperatures of about $5 \mathrm{~K}$. Helmert et al. (2007) detected a decrease of $3 \mathrm{~K}$ for more reflecting particles and $3.3 \mathrm{~K}$ for more absorbing ones as a regional average for the southern Sahara.

In our study we will analyse the observations and model results of two dust episodes that occurred over West Africa. We performed our model runs with the regional model system COSMO-ART (COSMO: COnsortium for Small-scale MOdelling, Steppeler et al., 2002; ART: Aerosols and Reactive Trace gases, Vogel et al., 2009). In contrast to the studies of Tulet et al. (2008) and Mallet et al. (2009) we consider the optical properties of the whole spectral range.

We simulated the influence of mineral dust particles on the state of the atmosphere for two dust episodes. The first episode is a dust outbreak that occurred during the African Multidisciplinary Monsoon Analysis (AMMA, Redelsperger et al., 2006) campaign in March 2006. The second episode occurred during June 2007 when the GERBILS (Geostationary Earth Radiation Budget experiment Intercomparison of Longwave and Shortwave radiation) field campaign took place in West Africa (Marsham et al., 2008).

The COSMO-ART model and the performed model runs are described in brief, and we give a short overview of the evolution of the dust storm in March 2006. We compare our model results with the available measurements. Especially, a detailed comparison of modelled and observed radiative fluxes is shown for Niamey.

We carried out two different model runs for each episode: the first one considers the feedback between mineral dust particles and radiative fluxes; the second one neglects it. On the basis of these runs we analyse the influence of dust particles on the radiative fluxes. We neglect the interaction of the mineral dust particles with cloud microphysics. Changes in near surface temperature caused by mineral dust are analysed for the episode in March where dust particles were located in the boundary layer and for the dust episode in June 2007 where also an elevated dust layer was found. Finally, we quantify the impact of the induced changes of the radiative fluxes on the emissions of dust particles.

\section{The COSMO-ART model system}

COSMO-ART (Vogel et al., 2009) describes the emission, the transport, and the deposition of gases and aerosols and their feedback with the physical state variables of the atmosphere. The model system is fully online coupled and identical numerical methods are applied to calculate the transport of all scalars. This also includes the treatment of deep convection with the Tiedtke scheme (Tiedtke, 1989), whereas 
Table 1. Classification of 13 different sand types. Each type contains information of up to three size distributions of particles including the median diameter $\left(d_{\mathrm{gs}}\right)$, the standard deviation $\left(\sigma_{\mathrm{s}}\right)$, and the fraction of erodible surface (fraction) (Chatenet et al., 1996). Additionally information about the residual soil moisture content $\left(w^{\prime}\right)$ is given (Fécan et al., 1999).

\begin{tabular}{lllll}
\hline Soil type & $d_{\mathrm{gs} 1}, d_{\mathrm{gs} 2}, d_{\mathrm{gs} 3}$ in $\mathrm{m}$ & $\sigma_{\mathrm{s} 1}, \sigma_{\mathrm{s} 2}, \sigma_{\mathrm{s} 3}$ & Fraction & $w^{\prime}$ \\
\hline Silty fine sand & $210 \mathrm{E}-6,125 \mathrm{E}-6,0$ & $1.8,1.6,0$ & $0.625,0.375,0$ & 1.05 \\
Medium sand & $210 \mathrm{E}-6,690 \mathrm{E}-6,0$ & $1.8,1.6,0$ & $0.2,0.8,0$ & 0.12 \\
Coarse sand & $0,690 \mathrm{E}-6,0$ & $0 ., 1.6,0$ & $0,1,0$ & 0 \\
Coarse medium sand & $210 \mathrm{E}-6,690 \mathrm{E}-6,0$ & $1.8,1.6,0$ & $0.1,0.9,0$ & 0.06 \\
Fine sand & $210 \mathrm{E}-6,0,0$ & $1.8,0,0$ & $1,0,0$ & 0.63 \\
Silty medium sand & $210 \mathrm{E}-6,690 \mathrm{E}-6,125 \mathrm{E}-6$ & $1.8,1.6,1.6$ & $0.3125,0.3125,0.375$ & 0.84 \\
Salty medium sand & $125 \mathrm{E}-6,520 \mathrm{E}-6,0$ & $1.6,1.5,0$ & $0.2,0.8,0$ & 0.8 \\
Salty silt fort & $125 \mathrm{E}-6,520 \mathrm{E}-6,0$ & $1.6,1.5,0$ & $0.08,0.92,0$ & 0.66 \\
Salt waste & $125 \mathrm{E}-6,520 \mathrm{E}-6,0$ & $1.6,1.5,0$ & $0.5,0.5,0$ & 1.16 \\
Sol agricole & $125 \mathrm{E}-6,0,0$ & $1.6,0,0$ & $1,0,0$ & 1.78 \\
Salty fine sand & $125 \mathrm{E}-6,520 \mathrm{E}-6,210 \mathrm{E}-6$ & $1.6,1.5,1.8$ & $0.1,0.4,0.5$ & 0.71 \\
Silty coarse sand & 690E-6, 125E-6, 0 & $1.6,1.6,0$ & $0.6,0.4,0$ & 0 \\
Other & $0,0,0$ & $0,0,0$ & $0,0,0$ & 0
\end{tabular}

the interaction of the mineral dust particles with cloud microphysics is not considered. Mineral dust particles are represented by log-normal distributions. Emission of dust particles are online calculated as functions of friction velocity, soil moisture, and surface parameters (Vogel et al., 2006).

\subsection{The dust emission scheme}

The dust emission scheme used in COSMO-ART developed by Vogel et al. (2006) combines a parameterisation of the threshold friction velocity after Lu and Shao (1999) with a parameterisation of the saltation process after Alfaro and Gomes (2001). The dust emission flux depends mainly on the friction velocity $u_{*}$. Dust emission takes place if $u_{*}$ is larger than the threshold friction velocity, which depends on soil water content and surface roughness. These dependences are parameterised after Fécan et al. (1999) and Alfaro and Gomes (1995). Other key parameters for the calculation of the dust emissions are the soil properties. We are using soil properties (Table 1) that were published by Marticorena et al. (1997) and Callot et al. (2000). The data set includes a classification of 13 different sand types. Each soil type contains information of up to three size distributions of particles including the median diameter and the standard deviation.

The calculation of the emission fluxes requires several input parameters for each surface grid box. Friction velocity and soil moisture are calculated within COSMO-ART at each time step. The fraction of erodible surface and the surface roughness are taken from the dataset of Chatenet et al. (1996). The residual soil moisture content, which is required for the calculation of the threshold friction velocity, is taken from Fécan et al. (1999).
COSMO-ART describes the size distribution of the mineral dust particles by three individual modes. The size distributions of each mode are approximated by a lognormal distribution with initial median diameters and standard deviations listed in Table 2 . The emission scheme is coupled online with the COSMO-ART model.

At each grid point up to five different soil types are taken into account. The vertical dust flux $\left(F_{\mathrm{tv}, i, \mathrm{~s}}\right)$ is calculated for each soil type $s$ separately. The individual fluxes are summed up weighted by the fraction $a(s)$ of the soil type s of each grid box:

$F_{\mathrm{tv}, i, \text { ges }}=\sum_{s=1}^{5} F_{\mathrm{tv}, i, \mathrm{~s}} \cdot a(s)$

This emission flux serves as the lower boundary condition for COSMO-ART.

\subsection{The radiation scheme}

The radiation scheme GRAALS that used in the COSMO model is based on the parameterisations of Ritter and Geleyn (1992). The transfer of shortwave and longwave radiation is calculated separately for non-cloudy and cloudy conditions. The scheme is based on the solution of the $\delta$ two-stream version of the radiative transfer equation. Effects of scattering, absorption and emission by aerosol particles, gases and cloud droplets are taken into account. The solar spectrum is divided into three spectral bands, which cover the wavelength interval between $0.25 \mu \mathrm{m}$ and $4.64 \mu \mathrm{m}$. The terrestrial spectrum covers the wavelength interval between $4.64 \mu \mathrm{m}$ and $104.5 \mu \mathrm{m}$. It is divided into five different spectral bands. Rayleigh scattering of molecules is considered for the shortwave spectral bands. 
Table 2. Statistical parameters for mineral dust particles after Alfaro and Gomes (1995).

\begin{tabular}{lrr}
\hline Mode & $\mathrm{dg}$ in $\mu \mathrm{m}$ & $\sigma$ \\
\hline 1 & 1.7 & 1.5 \\
2 & 6.7 & 1.6 \\
3 & 14.2 & 1.7 \\
\hline
\end{tabular}

Scattering and absorption by aerosols on the radiative transfer are considered in all spectral intervals. Therefore, the radiation scheme follows an approach of Tanre et al. (1984). For solving the radiative transfer equation the knowledge of the optical thickness for absorption and scattering and of the asymmetry parameter of the aerosol types is required for each spectral band.

In the operational COSMO model aerosol particles are not explicitly treated. Moreover their effect on atmospheric radiation is accounted for by prescribed optical properties with an exponential decrease with height. All aerosol optical properties are fixed in time. The aerosol types are classified as "urban", "continental", and "maritime" for the troposphere and "volcanic" and "stratospheric background aerosol" for the stratosphere. "Desert dust" aerosol is part of the "continental" aerosol type. "Rural" and "background tropospheric" aerosol are also assigned to this type of aerosol. The radiation scheme takes into account optical properties of these aerosol types for the eight spectral intervals.

"Desert dust" aerosol dominates the "continental" aerosol over Africa in the standard COSMO model (Helmert et al., 2007). Over the central Sahara the optical thickness at $550 \mathrm{~nm}$ wavelength for "desert dust" aerosol alone is greater than 0.6. It is decreasing towards higher latitudes.

In order to quantify the effect of the online calculated aerosol distribution of desert aerosol on the radiative fluxes and thereby on the state of the atmosphere we carried out control runs (CTRL) without the prescribed optical properties of desert dust aerosol.

\subsection{Online calculation of the optical properties within COSMO-ART}

During intensive mineral dust events the dust optical thickness can reach values greater than three over Africa and the distribution of dust particles has a high variability in time and space. Therefore, the fixed optical properties of the aerosol class "desert dust" that are prescribed in the operational COSMO model are replaced by the online calculated ones. The aerosol optical thickness for scattering and absorption is calculated from the extinction coefficient $b$ and the single scattering albedo $\omega$. These parameters and the asymmetry factor $g$ depend on particle size, number density and the complex refractive index of the particles. They are parameterised applying Mie theory. Particle size and number density distributions are calculated online with COSMOART.

The refractive index which is a crucial parameter for the Mie calculations depends on the wavelength of the radiation and the mineralogical composition of the dust particles. In reality the mineralogical composition and therefore the refractive indices differ for dust particles originating from different source regions. This is shown by several measurements (e.g. Petzold et al., 2009; Formenti et al., 2008). For our model runs we assume that the mineralogical composition of the dust particles does not vary in time and space. We used the shortwave refractive indices that were measured during the SAMUM (SAharan Mineral dUst experiMent) campaign (Petzold et al., 2009; red line in Fig. 1). In the longwave spectral range we used refractive indices provided by Tegen (personal communication; blue line in Fig. 1). They are derived with the assumption of a mineralogical composition of 98\% Kaolinite and 2\% Hematite (Helmert et al., 2007). An overview of different measured values of refractive indices for mineral dust particles is given in Fig. 1.

When calculating the optical properties we assume that dust particles are spherical. This assumption results in negligible errors when using a 2-stream approximation as GRAALS (M. I. Mishchenko, personal communication, 2008). Mallet et al. (2009) performed optical calculations using mixtures of oblate and prolate spheroids. They concluded that differences in the single scattering albedo and the asymmetry factor between these and spherical particles are lower than $10 \%$. With this assumption it is possible to derive the optical properties by applying Mie theory. The Mie code we use in our study is based on an algorithm provided by Bohren and Huffman (1983). The calculation of the optical properties at each grid point and at each time step is very time consuming. For that reason we calculate the specific extinction coefficient, the single scattering albedo and the asymmetry parameter a priori for the three initial dust size distributions. The median diameters and the standard deviation of those distributions are given in Table 2. The derived values for the specific extinction coefficient, single scattering albedo and asymmetry factor for the three dust modes for each wavelength are then interpolated and weighted with the solar radiance for determining the values for the 8 spectral bands. The results are presented in Table 3 . These values are input parameters for COSMO-ART.

Finally, the scattering and absorption optical thickness $\left(\tau_{\mathrm{s}, \mathrm{k}}, \tau_{\mathrm{a}, \mathrm{k}}\right)$, and the asymmetry factor $\left(g_{\mathrm{k}}\right)$ are calculated from the specific extinction coefficient $\left(\tilde{b}_{\mathrm{e}, \mathrm{n}, \mathrm{k}}\right)$, the single scattering albedo $\left(\tilde{\omega}_{\mathrm{n}, \mathrm{k}}\right)$, and the asymmetry factor $\left(\tilde{g}_{\mathrm{n}, \mathrm{k}}\right)$ for each mode $\mathrm{n}$ and spectral band $k$ : 
Table 3. Specific extinction coefficient $\left(\tilde{b}_{\mathrm{e}}\right)$, single scattering albedo $(\tilde{\omega})$, and asymmetry parameter $(\tilde{g})$ derived from Mie-calculations for the three dust modes (1-3) and the eight spectral bands $(k)$ used by COSMO-ART. The values of the specific extinction coefficients are given in $\mathrm{m}^{2} \mathrm{~g}^{-1}$.

\begin{tabular}{lrrrrrrrr}
\hline$k$ & 1 & 2 & 3 & 4 & 5 & 6 & 7 & 8 \\
\hline$\lambda$ in $\mu \mathrm{m}$ & $1.53-4.64$ & $0.7-1.53$ & $0.25-0.7$ & $20-104.5$ & $12.5-20$ & $8.33-9.01$ & $9.01-10.31$ & $4.64-8.33$ \\
& & & & & & $10.31-12.5$ & & \\
$\tilde{b}_{\mathrm{e}, 1, \mathrm{k}}$ & 0.606 & 0.543 & 0.481 & 0.070 & 0.136 & 0.178 & 0.400 & 0.220 \\
$\tilde{b}_{\mathrm{e}, 2, \mathrm{k}}$ & 0.293 & 0.262 & 0.248 & 0.086 & 0.151 & 0.229 & 0.306 & 0.243 \\
$\tilde{b}_{\mathrm{e}, 3, \mathrm{k}}$ & 0.257 & 0.232 & 0.222 & 0.090 & 0.157 & 0.230 & 0.280 & 0.239 \\
$\tilde{\omega}_{1, \mathrm{k}}$ & 0.975 & 0.983 & 0.890 & 0.105 & 0.150 & 0.409 & 0.353 & 0.515 \\
$\tilde{\omega}_{2, \mathrm{k}}$ & 0.949 & 0.970 & 0.832 & 0.226 & 0.323 & 0.575 & 0.476 & 0.589 \\
$\tilde{\omega}_{3, \mathrm{k}}$ & 0.943 & 0.967 & 0.821 & 0.258 & 0.367 & 0.590 & 0.491 & 0.594 \\
$\tilde{g}_{1, \mathrm{k}}$ & 0.665 & 0.668 & 0.749 & 0.097 & 0.198 & 0.392 & 0.233 & 0.659 \\
$\tilde{g}_{2, \mathrm{k}}$ & 0.814 & 0.737 & 0.659 & 0.140 & 0.307 & 0.489 & 0.451 & 0.779 \\
$\tilde{g}_{3, \mathrm{k}}$ & 0.681 & 0.746 & 0.823 & 0.156 & 0.345 & 0.512 & 0.517 & 0.798 \\
\hline
\end{tabular}
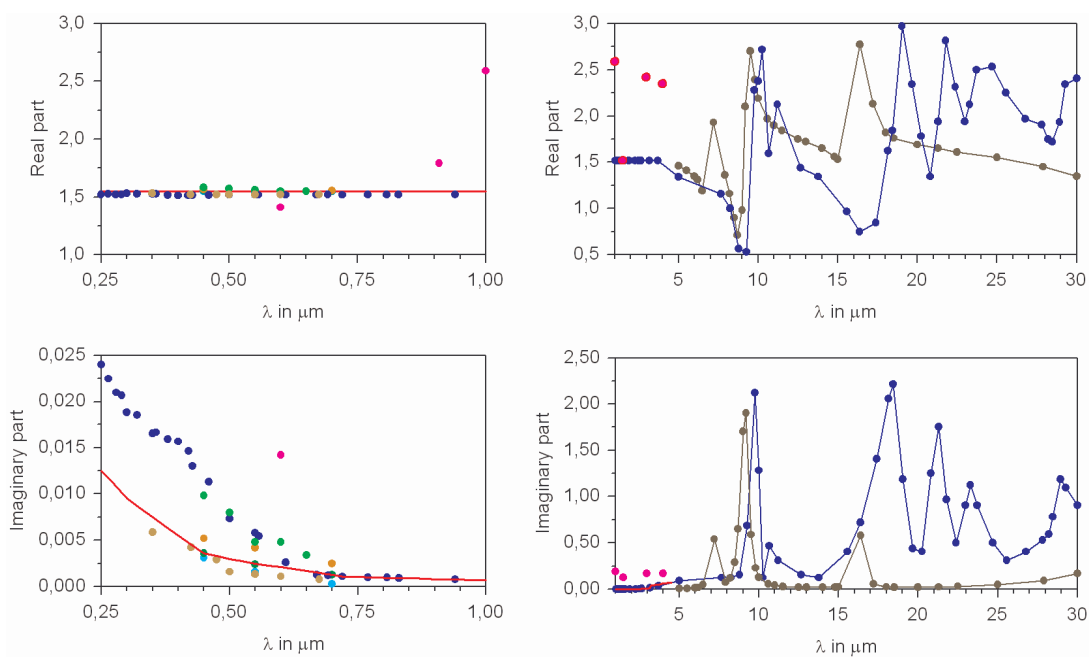

Fig. 1. Refractive indices for mineral dust of different studies (red: values used in run F; blue: Tegen, used in Helmert et al. (2007) and in the longwave spectrum in run F; pink: Volz (1973); brown: Sinyuk et al. (2003); green: Patterson et al. (1977); orange and light blue: Petzold et al. (2009) episodes 1 and 3; grey: Volz, 1972a, b and Shettle and Fenn, 1979).

$b_{\mathrm{e}, \mathrm{k}}(x, y, z)=\sum_{n=1}^{3} \tilde{b}_{\mathrm{e}, \mathrm{n}, \mathrm{k}} \cdot M_{\mathrm{n}}(\mathrm{x}, \mathrm{y}, \mathrm{z})$

$\omega_{k}(x, y, z)=\frac{1}{b_{\mathrm{e}, \mathrm{k}}(x, y, z)} \cdot \sum_{n=1}^{3} \tilde{\omega}_{\mathrm{n}, \mathrm{k}} \cdot \tilde{b}_{\mathrm{e}, \mathrm{n}, \mathrm{k}} \cdot M_{\mathrm{n}}(x, y, z)$

$b_{\mathrm{s}, \mathrm{n}, \mathrm{k}}=\tilde{\omega}_{\mathrm{n}, \mathrm{k}} \cdot \tilde{b}_{\mathrm{e}, \mathrm{n}, \mathrm{k}} \cdot M_{\mathrm{n}}(x, y, z)$

$g_{\mathrm{k}}(x, y, z)=\frac{1}{\sum_{n=1}^{3} b_{\mathrm{s}, \mathrm{n}, \mathrm{k}}} \cdot \sum_{n=1}^{3} \tilde{g}_{\mathrm{n}, \mathrm{k}} \cdot b_{\mathrm{s}, \mathrm{n}, \mathrm{k}}$

$\tau_{\mathrm{k}}(x, y, z)=b_{\mathrm{e}, \mathrm{k}}(x, y, z) \cdot(h(x, y, z)-h(x, y, z-1))$

$\tau_{\mathrm{s}, \mathrm{k}}(x, y, z)=\omega_{\mathrm{k}}(x, y, z) \cdot \tau_{\mathrm{r}}(x, y, z)$ $\tau_{\mathrm{a}, \mathrm{k}}(x, y, z)=\tau_{\mathrm{k}}(x, y, z)-\tau_{\mathrm{s}, \mathrm{k}}(x, y, z)$

The index $n$ refers to the three individual modes of mineral dust particles in COSMO-ART. $h(x, y, z)$ is the altitude of the model layer $z$ above the ground, $M_{\mathrm{n}}$ is the actual mass concentration of mineral dust of the mode $n$.

The calculations according to Eqs. (2-8) are carried out online within COSMO-ART. As the radiative fluxes are modified by the mineral dust particles changes in the wind field and thermal stability occur. This induces modifications of the friction velocity. The friction velocity plays a key role in the calculation of the dust emission within COSMO-ART. Changes in dust emission and meteorological parameters induce changes in dust concentration and by that are closing the feedback loop. 


\section{Model setup}

The simulation period for the synoptic induced dust storm is 5-10 March 2006. The period of the second dust event is 1924 June 2007. The simulation area for both episodes is West Africa (Fig. 2). The horizontal resolution for the model runs is $28 \mathrm{~km}$. In the vertical direction 40 layers are used up to a height of $22 \mathrm{~km}$. 16 layers are located below $2000 \mathrm{~m}$ above surface. We used a time step of $45 \mathrm{~s}$. Initial and boundary conditions are taken from the analyses of the IFS model of ECMWF (IFS: Integrated Forecast System; ECMWF: European Centre for Medium-Range Weather Forecasts). Initial and boundary conditions for mineral dust are set equal zero.

We replaced the surface albedo that is used in the standard COSMO model by data derived from MODIS data (Moderate Resolution Imaging Spectroradiometer; http:// www-modis.bu.edu/brdf/userguide/albedo.html) as it is done by the IFS model. While the maximum values are below or equal 0.3 in the standard version of the COSMO model the MODIS product gives values of about 0.5 for desert areas.

The calculation of the horizontal saltation flux requires the knowledge of the emission constant $C$ (Eq. 14; Vogel et al., 2006). This constant expresses the amount of material which is available for emission. This amount can vary during a dust event. White (1979) derived a value for $C$ of 2.61 by theoretical considerations, whereas Gomes et al. (2003) found $C=0.02$ during a field experiment in Spain. In our simulations we used $C=0.8$.

Two different model runs were carried out for each dust episode. Run F includes the feedback between mineral dust particles and radiative fluxes. In run CTRL this feedback is neglected but the emission and transport of dust particles is considered. The radiation routine was called once per hour. With this configuration of model runs we determine the interaction of dust particles and the thermodynamic and dynamic processes over West Africa.

\section{Comparison with observations}

\subsection{The case of March 2006}

In March 2006 one of the biggest dust storms during the last years took place. It developed over Morocco and Algeria on 5 March 2006 when a cold front of a cyclone over the Balearic Islands reached Northern Africa. During the following days the cold front crossed West Africa accompanied by the dust storm. A description of the synoptic-dynamic evolution of the dust storm is included in Milton et al. (2008). They point out the similarity to a dust storm over West Africa in March 2004, which was analysed in detail by Knippertz et al. (2006).

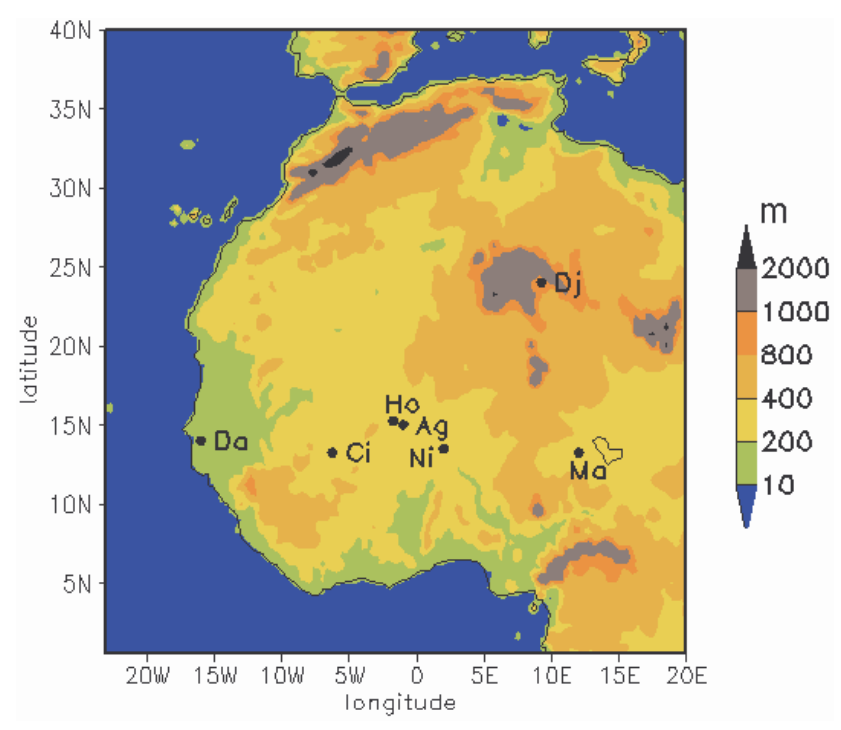

Fig. 2. Model domain and stations used for comparison with model results. (Ag - Agoufou, Ci - Cinzana, Da - Dakar, Dj - Djanet, Ho - Hombori, Ma - Maine Soroa, Ni - Niamey).

\subsubsection{Comparison with satellite data}

Figure 3 shows the modelled AOD at $450 \mathrm{~nm}$ (left) and the EUMETSAT RGB dust product at $550 \mathrm{~nm}$ (right) and retrieval derived from MODIS satellite data (http://daac.gsfc. nasa.gov/giovanni/). The RGB dust product is derived from differences amongst three SEVIRI infrared channels $(8.7 \mu \mathrm{m}$, $10.8 \mu \mathrm{m}$, and $12.0 \mu \mathrm{m})$. Dust appears in pink, high optically thick and cold clouds are coloured in dark red. The EUMETSAT products are available for every hour. The MODIS retrievals are derived for each single day using the overpasses of the model domain.

During 5 March 2006, around noontime, high concentrations of mineral dust particles occur over Algeria and Libya. A cold front moves to the south accompanied by the dust storm.

At noon of 6 March, significant dust concentrations are simulated over West Africa north of $16^{\circ} \mathrm{N}$ except in Morocco and north-west Algeria. The dust particles are transported with high wind speeds in southerly directions. Algeria, Libya, and parts of Mauritania and Mali are under the influence of the dust storm on 6 March, 12:00 UTC (Fig. 3, top). The position of the simulated dust storm is in good agreement with the observed one given by the dust product but shows a shift (delay) of about $200 \mathrm{~km}$ in comparison with the MODIS deep blue retrievals. However one has to take into account that the MODIS retrievals are a superposition of two overpasses between 12:00 UTC and 14:00 UTC.

On 7 March 2006 12:00 UTC, the observed dust front moves across the Hoggar, Air and Tibesti mountains. The flow is channelled by the topography and wind speed close to the surface increases. The intensification of the dust plume 

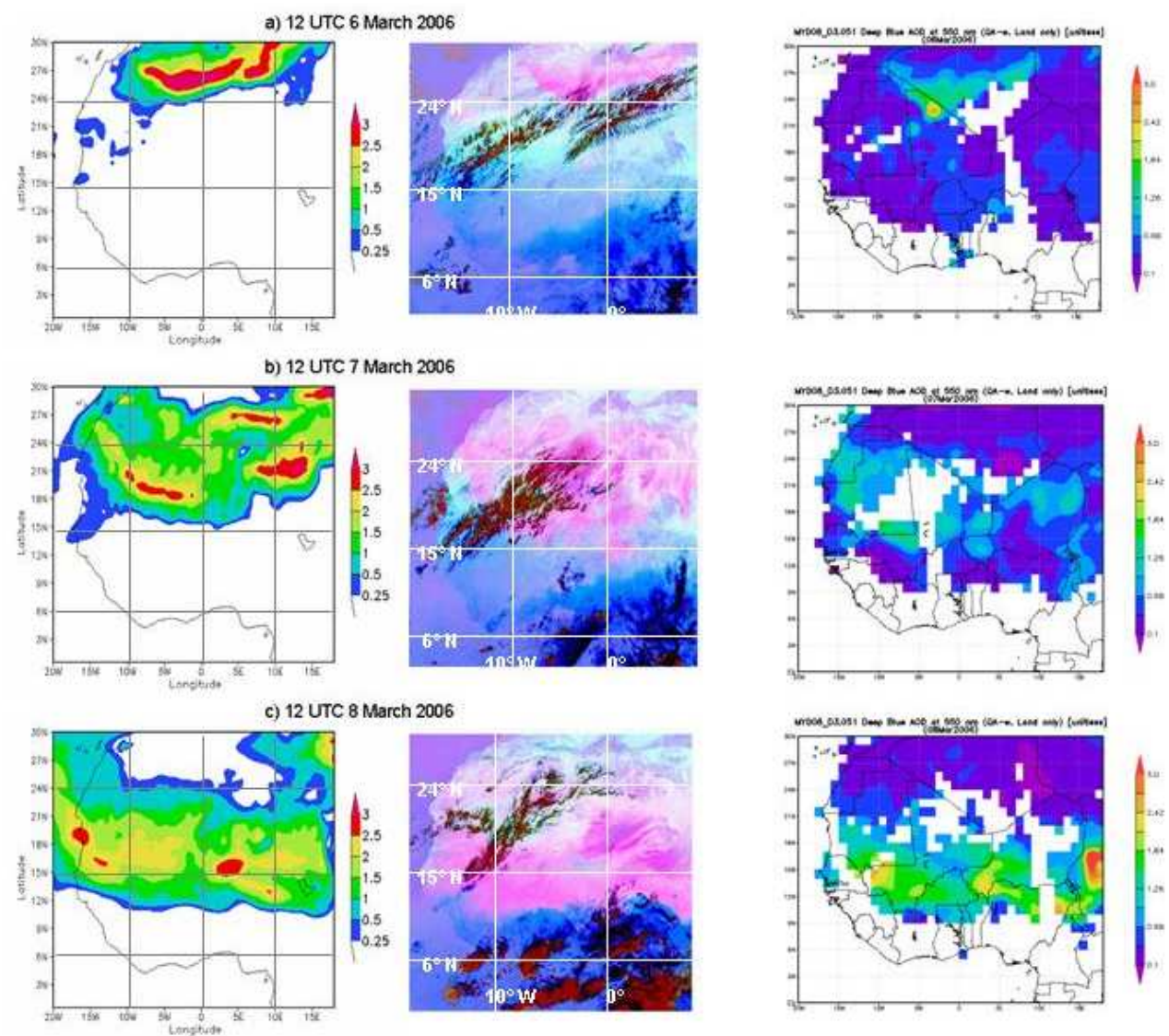

Fig. 3. Simulated AOD at $450 \mathrm{~nm}$ of run F (left) and SEVIRI RGB dust product with dust shown in pink and cold high clouds in dark red (middle) and MODIS deep blue AOD retrievals at $550 \mathrm{~nm}$.

in these areas (Fig. 3, middle) is indicated by the simulation. The small scale structure of the observed dust front cannot be resolved by the model results due to the horizontal resolution of $28 \mathrm{~km}$. The general position of the simulated dust storm shows still a spatial delay of about $200 \mathrm{~km}$.

Based on the relative vorticity which is a good indicator for the cold front we derived the propagation of the dust front. On 6 March the position of the front is located around $28^{\circ} \mathrm{N}$. Twenty-four hours later the front line is calculated to be around $10^{\circ}$ further south. That means that the obtained mean velocity of the front was $13 \mathrm{~m} \mathrm{~s}^{-1}$.

One day later ( 8 March) the dust storm has propagated further to the south. The simulated emission fluxes are now smaller than the day before (Fig. 12). The position of the dust front is well reproduced by COSMO-ART. Small differences in the position and the structure especially in the south-east of the dust front are due to the coarse resolution. The simulated AOD values show higher peak values than the satellite data.

\subsubsection{Comparison with sun photometer data}

A quantitative comparison of the dust evolution can be gained using AERONET stations (AErosol RObotic NETwork). In March 2006, the following AERONET stations located in our model domain performed measurements: Dakar, Agoufou, Maine Soroa, Cinzana, Tamanrasset, Banizoumbou, Djougou, Quagadougou, and Ilorin. We restrict to show the comparisons of observations and model results for the first four stations (Fig. 4). The comparisons for the other stations give similar results. We compare the observed AOD at $440 \mathrm{~nm}$ with the simulated ones at $450 \mathrm{~nm}$.

In general COSMO-ART captures the rise of the AOD during 7-9 March quite well. But the maxima in observed AOD are underestimated by the model. The temporal evolution of the observed AOD is well reproduced by the modelled one for Dakar (Fig. 4). The comparison between modelled and observed AOD in Agoufou and Cinzana shows a delay in the simulated arrival of the dust front (Fig. 4). On 5 March the AOD is significantly underestimated for Maine Soroa by the model results. This is caused by the fact, that we start our simulations with a dust free atmosphere. Therefore the model is not able to capture the observed values at 

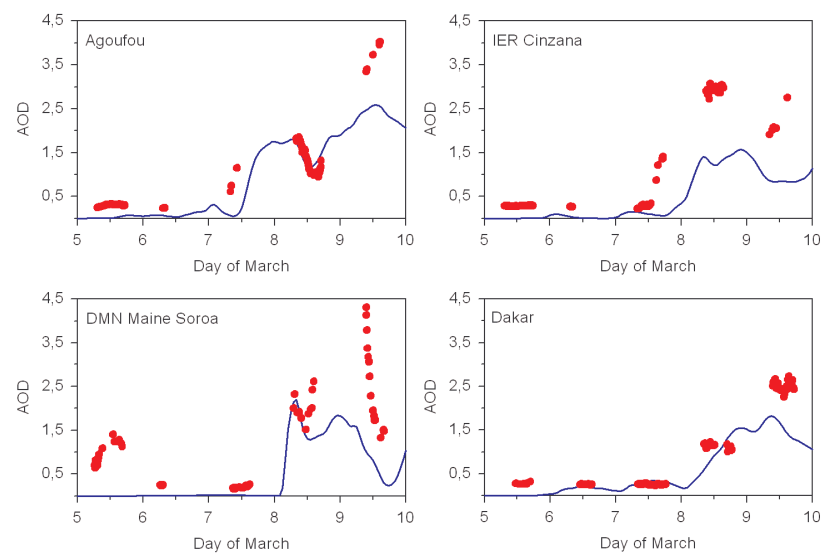

Fig. 4. Simulated (blue) AOD at $450 \mathrm{~nm}$ and measured AOD at $440 \mathrm{~nm}$ (red) at AERONET stations during 5-10 March 2006.

the beginning of the simulation period. Our results are comparable to those of Tulet et al. (2008) for Ilorin and Djougou, and those of Milton et al. (2008) for Agoufou, Dakar, Cape Verde, Cinzana, Banizoumbou, Djougou, and Maine Soroa. The reason for the differences between model results and observed AOD could be both an imprecise calculated mass concentration and the uncertainties of the refractive index and the size distributions that are used to calculate the optical properties. Another reason for the differences of modelled and measured AOD could be that the simulated AOD takes only dust particles into account whereas the measurements capture also other aerosol types. During the first three days (5-7 March) the measured Ångstrom coefficient $(440 \mathrm{~nm}$ and $870 \mathrm{~nm}$ ) at Dakar is higher than 0.4. This indicates smaller particles like biomass burning aerosol. When the dust front reaches the station the value declines to less than 0.15 , indicating larger particles. So the increase of observed AOD is due to the arrival of dust particles.

\subsubsection{Comparison with data from SYNOP stations}

We used the data of the SYNOP stations Hombori and Djanet (WMO No. 612400, 606700) for comparison. Djanet is located east of the Hoggar, Hombori is located further south (Fig. 2). Figure 5 shows time series of observed visibility and simulated AOD at $450 \mathrm{~nm}$ and observed and simulated $2 \mathrm{~m}$ temperature.

Observed visibility and simulated AOD are anti correlated at both stations. As the simulated dust is located in the boundary layer our model reproduces the arrival of the dust front and the further development at both stations very well.

The dust front arrives at Djanet during the night of 6-7 March 2006 and the observed temperature decreases. The runs $\mathrm{F}$ and CTRL reproduce the decrease in temperature during the arrival of the dust front. This indicates that the decrease in temperature of about $10 \mathrm{~K}$ is caused by the passage of the cold front arriving simultaneously. After the arrival of
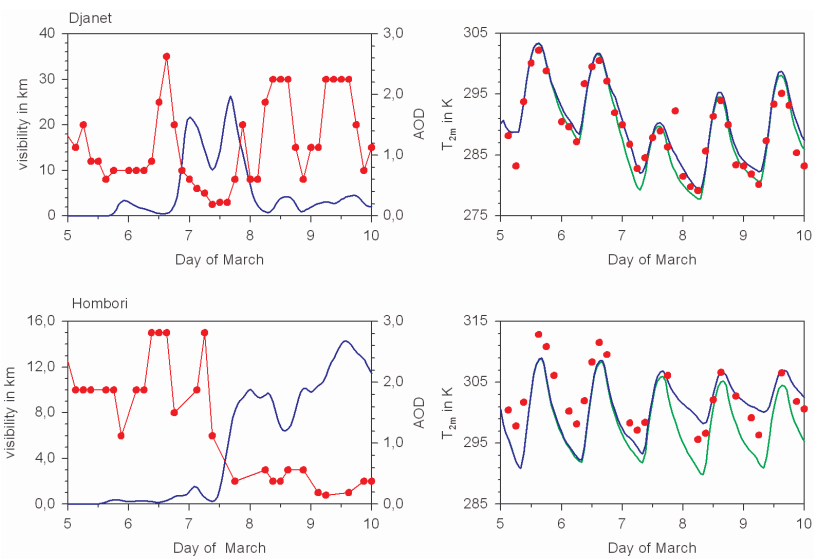

Fig. 5. Observed visibility (red) and simulated AOD (blue) at $450 \mathrm{~nm}$ (run F) at Djanet and Hombori during 5-10 March 2006 (left) and corresponding observed and simulated $2 \mathrm{~m}$ temperature (right). Observations: red, run F: blue, run CTRL: green.

mineral dust the $2 \mathrm{~m}$ temperature is better reproduced by run $\mathrm{F}$ than by run CTRL. The observed daily temperature range decreases from $14.1 \mathrm{~K}$ on 5 March to $6.2 \mathrm{~K}$ on 7 March (Table 4). The simulated daily temperature range is reduced by $6.3 \mathrm{~K}$ in run $\mathrm{F}$ and by $4.1 \mathrm{~K}$ in run CTRL. A part of the reduction is due to the passage of the cold front but the presence of the dust particles causes a further reduction of the daily temperature range. The high dust concentrations remain at the station for about $30 \mathrm{~h}$. Then the simulated AOD decreases again and the observed visibility increases (Fig. 5).

The dust front reaches Hombori during noon on 7 March. The observed visibility decreases from $16 \mathrm{~km}$ to $2 \mathrm{~km}$ (Fig. 5). The AOD of run F increases. In contrast to Djanet the visibility remains at low and the AOD at high values for a much longer time period.

During the first two days of the simulation period the $2 \mathrm{~m}$ temperature is underestimated in both model runs (Fig. 5). Due to the horizontal grid size of $28 \mathrm{~km}$ the land use in the model differs from the actual one at Hombori. That explains the underestimation of the $2 \mathrm{~m}$ temperature (see Sect. 5.2). After the dust front passed the station the observed daily temperature range is reduced by more than $4 \mathrm{~K}$. Like in Djanet this reduction is reproduced by run $\mathrm{F}$, but at the end of the simulation period it is overestimated (Table 4).

Surprisingly, at both stations the simulated temperature of run $\mathrm{F}$ is higher than the one of run CTRL during night and day. One would expect that the reduction in surface downward shortwave radiative flux due to absorption and scattering of radiation should induce a decrease in near surface temperature during noon. This behaviour will be discussed in more detail in Sect. 5.2. 
Table 4. Observed and simulated daily temperature range (DTR) in $\mathrm{K}$ for Djanet and Hombori.

\begin{tabular}{lrrrrr}
\hline & \multicolumn{5}{c}{ Date } \\
\cline { 2 - 6 } & 5.3. & 6.3. & 7.3. & 8.3. & 9.3. \\
\hline Djanet, observed & 14.1 & 13.4 & 6.2 & 14.8 & 15 \\
Djanet, run F & 14.6 & 13.3 & 8.3 & 16.3 & 16.4 \\
Djanet, run CTRL & 14.6 & 14.2 & 10.5 & 16.7 & 17.4 \\
Hombori, observed & 15 & 13.4 & 9 & 11 & 10.2 \\
Hombori, run F & 18.1 & 16.3 & 13.1 & 8.4 & 6.9 \\
Hombori, run CTRL & 18.1 & 16.4 & 14.1 & 15.4 & 13.5 \\
\hline
\end{tabular}

\subsubsection{Comparisons with flux measurements at Niamey}

Detailed measurements of the radiative fluxes at the surface were carried out at the ARM Mobile Facility (hereafter ARM-MF) in Niamey, Niger $\left(13.52^{\circ} \mathrm{N}, 2.11^{\circ} \mathrm{E}\right)$. The deployment of the ARM-MF was part of the RADAGAST (Radiative Atmospheric Divergence Using ARM Mobile Facility, GERB Data, and AMMA Stations) project (Miller and Slingo, 2007).

The time series of observed and modelled AOD in Niamey between 5 March, 00:00 UTC and 10 March 2006, 00:00 UTC is shown in Fig. 6a. Slingo et al. (2006) made retrievals of the AOD from data obtained with the Multi-Filter Rotating Shadowband Radiometer (MFRSR). They derived the aerosol optical properties from MFRSR observations by using an updated version of the retrieval technique described by Kassianov et al. (2005). We used the retrievals at $415 \mathrm{~nm}$ of Slingo et al. (2006, Fig. 2) for a comparison with the modelled AOD at $450 \mathrm{~nm}$ for run F and CTRL (Fig. 6a).

The observation shows that the dust front arrived in $\mathrm{Ni}$ amey on 7 March at noon whereas the simulation of the AOD shows a delay of approximately $5 \mathrm{~h}$. The simulated AOD is too low during the first two days after the passage of the front and the observed maximum is not captured in the simulation. Milton et al. (2008) found similar differences between observations and model results for the station at Niamey. They suppose that the reason could be poorly modelled dust sources, an incorrect soil moisture state, or deficiencies in the modelled near surface wind. These reasons would hold for our model runs as well. Moreover, we would add uncertainties of the simulated size distributions, mineralogical composition, and consequently the obtained optical properties of the dust particles. Observed and simulated AOD of run $\mathrm{F}$ are in a good agreement on 9 March.

Figure $6 \mathrm{~b}$ shows the daily cycles of measured and simulated downward shortwave radiative flux at the surface. The observed flux decreased due to the presence of mineral dust particles at noon of 7 March. As a result of the temporal delay of the modelled dust front the decrease of the surface downward shortwave radiative flux is reproduced in run $\mathrm{F}$
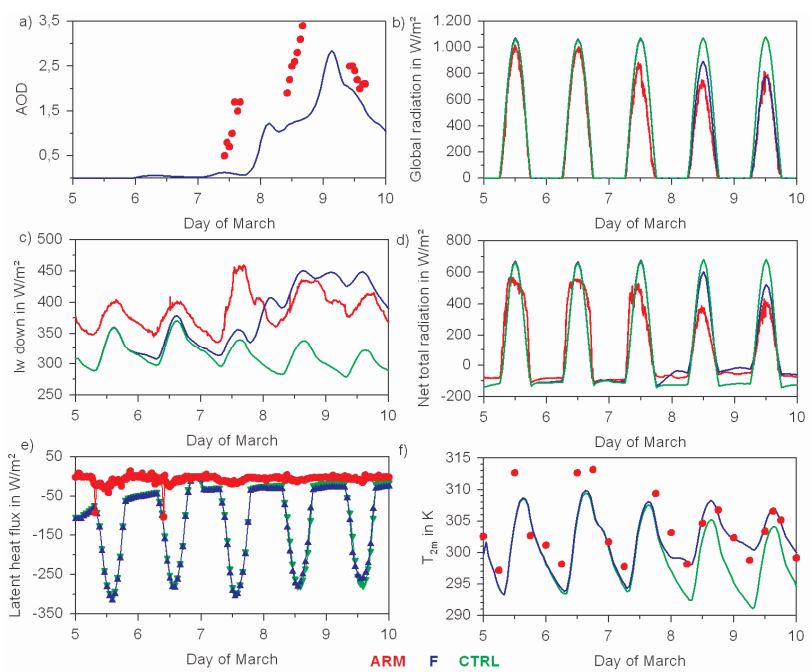

Fig. 6. Simulated AOD at $450 \mathrm{~nm}$ and observed AOD at $415 \mathrm{~nm}$ (taken from Slingo et al. (2006), Fig. 2), shortwave downward radiation, longwave downward radiation, net radiation, latent heat flux, and $2 \mathrm{~m}$ temperature during 5-10 March 2006 at Niamey. Observations: red, run F: blue, run CTRL: green.

with a delay of one day. On 9 March the simulated and the observed AOD values are similar and also the simulated and the observed surface downward shortwave radiative flux are in a good agreement. With prevailing cloud free conditions the flux stays constant from day to day in run CTRL. In this run the surface downward shortwave radiative flux is overestimated by more than $300 \mathrm{~W} \mathrm{~m}^{-2}$ after the passage of the dust front.

Slingo et al. (2006) showed that most of the surface downward shortwave radiative flux is attributed to the diffuse component. Our simulation underestimates the diffuse flux and overestimates the direct flux (Stanelle, 2008). One reason for these deviations could be that the observed aerosol population has a larger single scattering albedo than our simulated ones. This could be caused by a smaller imaginary part of the refractive index or by smaller particles.

The observed upward longwave flux is larger than the simulated one because the observed temperature is higher than the simulated one (Fig. 6f). After the passage of the cold front the observed downward longwave flux is increasing although the observed temperature is decreasing (Fig. 6c, f). This can be attributed to the mineral dust and is reproduced by the results of run F. The increase in longwave radiation is slightly overestimated by the model results. In contrast the temperature and simultaneously the downward flux of longwave radiation are decreasing in run CTRL. The different behaviour clearly demonstrates the effect of the mineral dust particles on the longwave downward flux.

Figure $6 \mathrm{~d}$ shows the simulated surface radiation budget at Niamey for five consecutive days. The surface radiation budget is given by the sum of net shortwave and net longwave 
radiative fluxes. Before the arrival of the dust front the simulated surface radiation budget is higher than the observed one during daytime hours. This is caused by the underestimation of the simulated upward longwave flux due to the underestimation of the temperature. The reason for the underestimation of the temperature is given below.

After the arrival of the dust front a reduced surface radiation budget is observed during the day. On 9 March the simulated AODs of run $\mathrm{F}$ are in good agreement with the observed ones. At that day the observed and the simulated reduction of the surface radiation budget during daytime caused by mineral dust (e.g. 5 March) are comparable (observed: $150 \mathrm{~W} \mathrm{~m}^{-2}$, simulated: $160 \mathrm{~W} \mathrm{~m}^{-2}$ ). However, in run $\mathrm{F}$ the observed surface radiation budget is overestimated during daytime and underestimated during night time before the passage of the dust front. After the passage it is overestimated during night time. There are several reasons for the overestimation during daytime. One reason is the underestimation of upward shortwave flux due to differences between the real surface albedo and the one that was used in the model. Another reason is the overestimation in the downward longwave flux and of the radiative balance during night and day as well.

The overestimation of the surface radiation budget should lead to an overestimation of the surface temperature. However, the surface temperature is underestimated by the model. Figure 6e shows the temporal development of the observed and the simulated latent heat flux. It is obvious that the simulated fluxes are much higher than the observed ones. This is caused by the resolution of our model. While the ARM mobile facility was placed at bare soil in our model runs savannah type vegetation is present at the corresponding grid point. This results in an overestimation of the simulated latent heat flux by the model. Apart from that discrepancy, which we expect to be same for both runs, we can use the observations and the results of the simulation to compare the effects caused by mineral dust. We calculated the observed and the simulated daily temperature range for each day (Table 5). The maximum temperature decreases in run $\mathrm{F}$ and run CTRL during 7-8 March. As for Djanet and Hombori the temperature decrease of run CTRL at Niamey is due to the cold front. When the simulated dust front has reached the station the results of run F and CTRL starts to differ. Especially during night much higher temperatures are simulated in run $\mathrm{F}$. This is caused by an increased downward longwave flux due to the mineral dust particles. In agreement with the observations the maximum temperature in run F stays constant after the mineral dust has reached the station whereas it continues to decrease in run CTRL. Another remarkable effect is a distinct decrease in the daily temperature range. After the arrival of the dust front the daily temperature range is strongly overestimated by neglecting the influence of dust particles on radiative fluxes (run CTRL). A similar behaviour was already found for the station Hombori.
Table 5. Observed and simulated daily temperature range (DTR) in $\mathrm{K}$ for Niamey.

\begin{tabular}{lrrrrr}
\hline & \multicolumn{5}{c}{ Date } \\
\cline { 2 - 6 } & 5.3. & 6.3. & 7.3. & 8.3. & 9.3. \\
\hline Observations & 15.5 & 15.0 & 11.6 & 8.6 & 7.8 \\
run F & 15.4 & 16.1 & 13.8 & 10.0 & 6.5 \\
run CTRL & 15.4 & 16.1 & 13.8 & 12.7 & 13.0 \\
\hline
\end{tabular}

\subsection{The case of June 2007}

During the boreal summer the circulation is dominated by the monsoon system in West Africa. The Intertropical Convergence Zone (ITCZ) is shifted northwards; the rather cold and moist monsoon flow penetrates into West Africa. A characteristic of the West African monsoon is the Inter Tropical Front (ITF). There the dry Harmattan flow is separated from the moist monsoon flow. The Harmattan is increased by the Saharan heat low, which is a shallow pressure system covering major parts of the Saharan desert. Due to the convergence in the region of the ITF the air mass and therefore the dust emitted in the area covered by the Harmattan is forced to ascent. In opposite to the dust storm in March 2006 the more local dust events during 20-24 June 2007 did not affect entire West Africa. During these events the dust particles were located close to the surface and after uplifting along the ITF also in elevated layers. Information about the precise synoptic conditions during the dust storms in June 2007 can be found in Grams et al. (2010).

\subsubsection{Comparison with satellite data}

In the following we will compare the simulated AOD values at $450 \mathrm{~nm}$ with EUMETSAT RGB dust products and retrieved AOD values at $550 \mathrm{~nm}$ derived from MODIS satellite data. On 21 June 2007 the MODIS overpasses covered the time intervals 12:55-13:05 and 14:35-14:40 UTC on 21 June.

On 20 June, 2007 a first major dust plume is simulated over Mali. The emission of dust particles took place northerly of the ITF. During the following night the dust plume was transported in south-westerly directions. The position of the simulated dust plume is in a good agreement with the observed one on 21 June, 08:00 UTC (Fig. 7 top, bulb 1). Another maximum of AOD over Morocco is simulated in the region of the Atlas Mountains which can not be recognized in the satellite image. This cloud of mineral dust moves north-eastwards and does not influence the results in the examined areas farther south.

In the afternoon a second dust plume is simulated (Fig. 7 middle and bottom, bulb 2). This second dust plume is also visible in the EUMETSAT dust product. The orientation of 

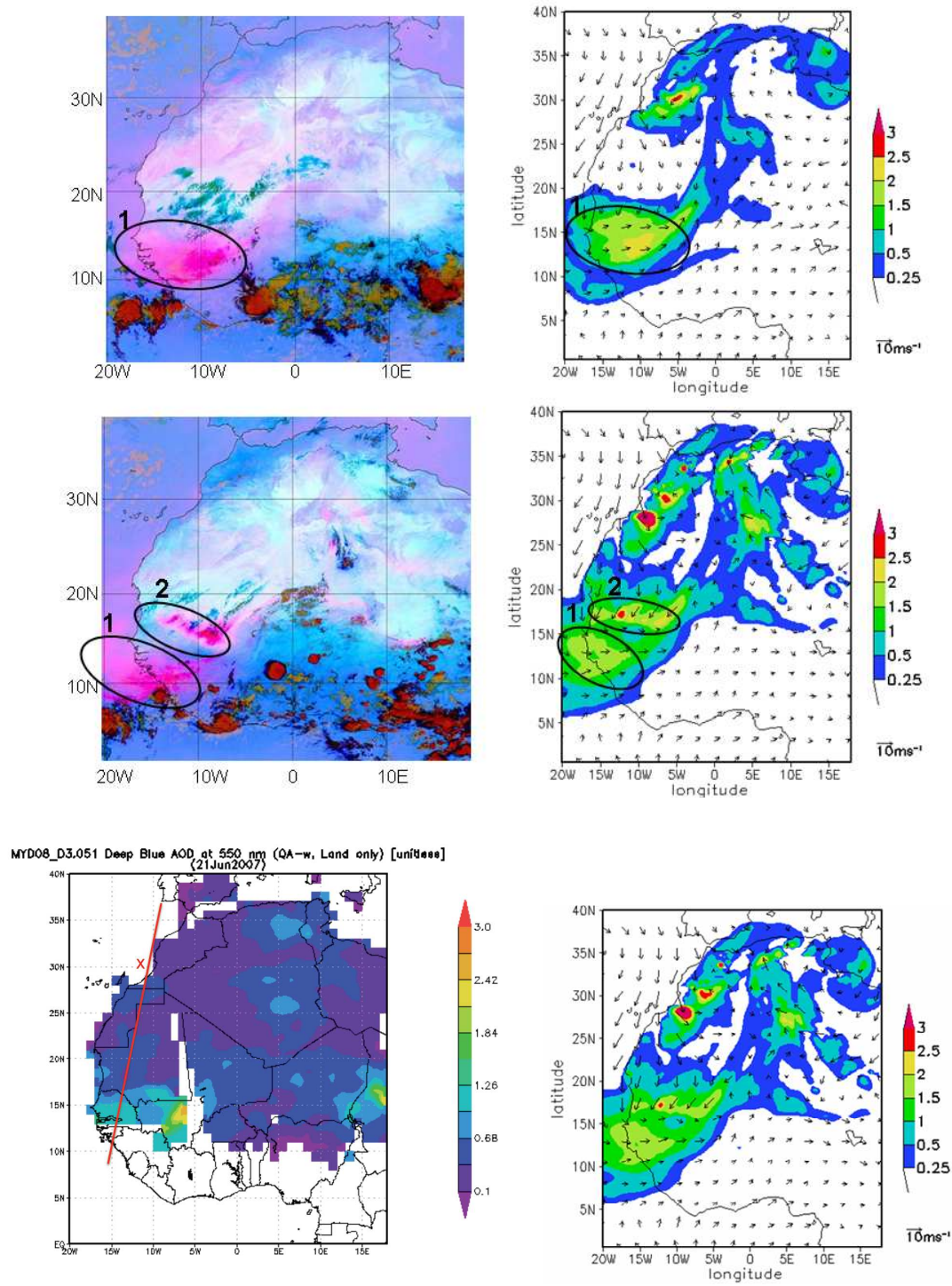

Fig. 7. Simulated AOD at $450 \mathrm{~nm}$ and $10 \mathrm{~m}$ wind vectors of run F (right) and SEVIRI RGB dust product with dust shown in pink and cold high clouds in dark red (left) on 21 June 2007, 08:00 UTC (top) and 16:00 UTC (middle). MODIS deep blue AOD at 550 nm, simulated $\mathrm{AOD}$ at $450 \mathrm{~nm}$ (run F) and simulated wind vectors at 15:00 UTC (bottom).

this plume is simulated by the model not entirely correct and it is located too far to the north. It is possible that this error is a result of a wrong location of the ITF, as strong dust emission is closely related to the location of the ITF. Comparing ECMWF-4D-Var-Analysis and measurements for July 2006 (time period of AMMA-SOP 2006), Messager et al. (2010) found the analysis locating the ITF too far to the north. Perhaps this could be the case for the examined time period as well and with the ECMWF-Analysis taken as boundary data for the model run this could explain the incorrect location of this dust emission. At 15:00 UTC 21 June a comparison with the MODIS data is possible (Fig. 7, bottom). The satellite data shows the dust plume 2 but not the plume 1 which is located in an area of missing data. While again differences occur in the exact location of the dust plume the maximum values of the AOT are comparable.

In order to compare the vertical structure of the simulated dust distribution with observations we used CALIOP data (Cloud-Aerosol-LIdar with Orthogonal Polarization, Winker et al., 2007). The CALIOP-derived perpendicular attenuated backscatter coefficient at $532 \mathrm{~nm}$ is shown on the bottom of Fig. 8 for 22 June 2007 between 02:40 UTC and 02:54 UTC. The signal strength has been colour coded. Blue correspond to molecular scattering and weak aerosol scattering; aerosols generally show up as yellow, red and, orange. Strong cloud signals are shown in grey, while weaker cloud returns are similar in strength to strong aerosol signals, they are coded in yellow and red. The simulated vertical distribution of dust 


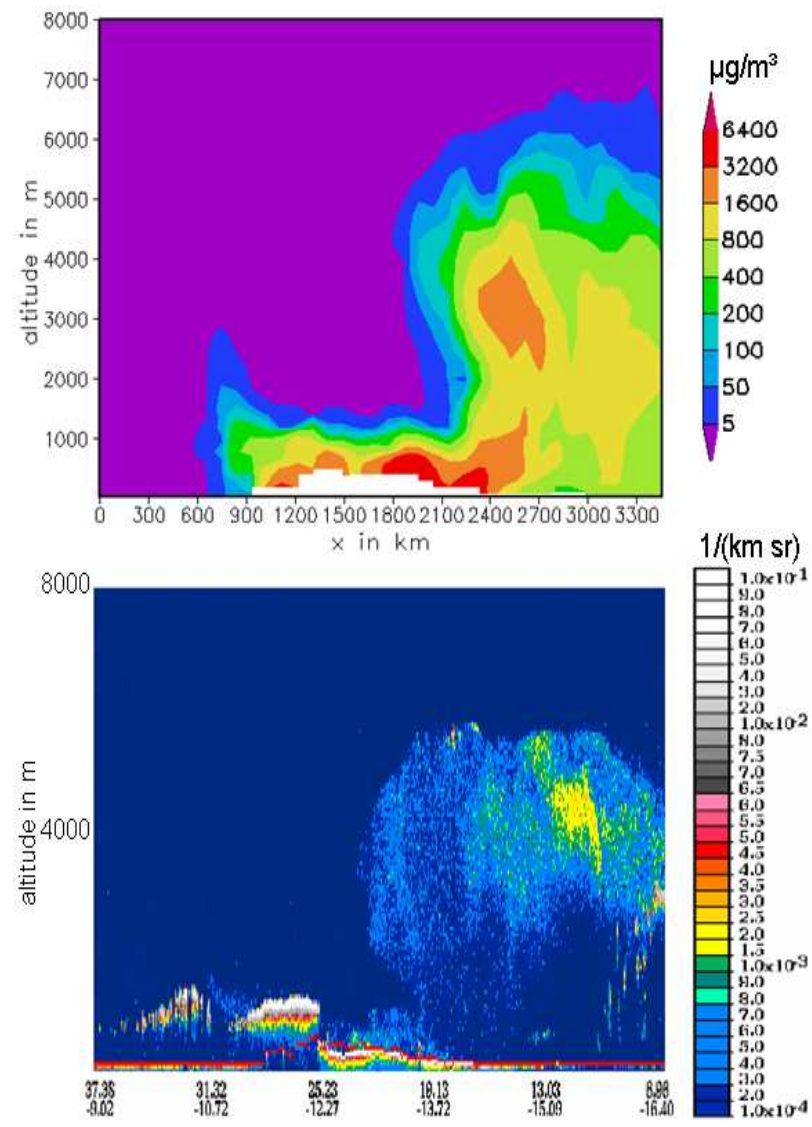

Fig. 8. Top: vertical cross section between $37.5^{\circ} \mathrm{N}, 9^{\circ} \mathrm{W}$ and $7^{\circ} \mathrm{N}, 16.5^{\circ} \mathrm{W}$ for the simulated mass density on 22 June 2007 , 03:00 UTC. Bottom: CALIPSO lidar-derived attenuated backscatter coefficient at $532 \mathrm{~nm}$ along the CALIPSO track (between $37.38^{\circ} \mathrm{N}, 9.02^{\circ} \mathrm{W}$ and $6.96^{\circ} \mathrm{N}, 16.4^{\circ} \mathrm{W}$, indicated by $\mathrm{x}$ in Fig. 7 , bottom) on 22 June 2007 between 02:40 and 02:54 UTC.

particles is shown by a cross section of the mass concentration in the top of Fig. 8 for the same day at 03:00 UTC.

The dust particles are situated close to the surface in the north eastern part of the cross section in both observation and simulation. The altitude of the dust layer is approximately $1.3 \mathrm{~km}$. When the dust particles are in the region of the ITF they are uplifted by strong vertical winds. This behaviour is shown by the observation as well as by the simulation.

\section{Discussion of the model results}

Based on our model results we will quantify the impact of mineral dust on the radiative fluxes, the temperature and the feedback between dust particles and their emissions in more detail.

\subsection{Impact of mineral dust particles on radiative fluxes}

We calculated the differences in net radiative flux $(\Delta F)$ caused by mineral dust between the results of runs $\mathrm{F}$ and CTRL at 7 March 2006, 8 March 2006 and 21 June 2007, 12:00 UTC at the surface. Only grid points are used where the cloud cover was zero in runs F and CTRL. Based on other studies, $\Delta F /$ AOD is called the dust forcing efficiency (e.g. Helmert et al., 2007). Close to source areas in southern Sahara Helmert et al. (2007) found a dust forcing efficiency of $-196 \mathrm{~W} \mathrm{~m}^{-2}(\mathrm{AOD}=1$, at $500 \mathrm{~nm})$ for particles with high single scattering albedo and $-220 \mathrm{~W} \mathrm{~m}^{-2}$ for particles with a lower single scattering albedo. Averaged over northern Sahara they found $-81 \mathrm{~W} \mathrm{~m}^{-2}$ and $-85 \mathrm{~W} \mathrm{~m}^{-2}$, respectively. Fouquart et al. (1987) found a dust forcing efficiency of $-145 \mathrm{~W} \mathrm{~m}^{-2}(\mathrm{AOD}=1$, at $550 \mathrm{~nm})$ during a field campaign near Niamey. Mallet et al. (2009) determined similar numbers.

The dependency of $\Delta F$ on AOD at $450 \mathrm{~nm}$ for our model results is shown in Fig. 9 for 12:00 UTC for all grid points with an AOD greater than 0.1. We found an average forcing efficiency of $-140 \mathrm{~W} \mathrm{~m}^{-2}$ for the net shortwave flux at the surface.

In contrast to the linear behaviour in ratio of $\Delta F$ and AOD for the net shortwave flux at the surface, we found a nonlinear relation between the net longwave flux and AOD and $\Delta F$ levels out at about $150 \mathrm{~W} \mathrm{~m}^{-2}$ (Fig. 9). This is in good agreement with the value determined by Milton et al. (2008).

Helmert et al. (2007) determined a shortwave dust forcing efficiency at the top of the atmosphere (TOA) of $-121 \mathrm{~W} \mathrm{~m}^{-2}$ close to the source areas and $-55 \mathrm{~W} \mathrm{~m}^{-2}$ at larger distances. In contrast to that we found at most grid points positive values. Figure 9 shows the relationship between $\Delta F$ and the AOD at TOA. This relationship is not as clear as at the surface. However, $\Delta F$ is not only determined by the AOD. We correlated $\Delta F$ with the surface albedo (not shown here) and obtained a very clear positive correlation. Negative values of $\Delta F$ are only found at those grid points where the surface albedo is below 0.27 i.e. over the ocean. This dependency on the surface albedo was already explained by Liao and Seinfeld (1998). In contrast to our simulation Helmert et al. (2007) used the albedo of the operational COSMO version i.e. a maximum albedo below 0.3 whereas in our setup of the model the maximum value is 0.5. This explains the differences in the sign of the shortwave forcing efficiency.

Haywood et al. (2005) applied the UK Met Office Unified Model and found discrepancies between modelled and observed longwave radiative flux on TOA above the Saharan heat low. They identified the lack of mineral dust in the model as a major reason of this systematic error. They got an overestimation in outgoing longwave radiation by cloud free conditions of up to $50 \mathrm{~W} \mathrm{~m}^{-2}$ (daily mean) which implies an underestimation of net longwave flux on TOA. 

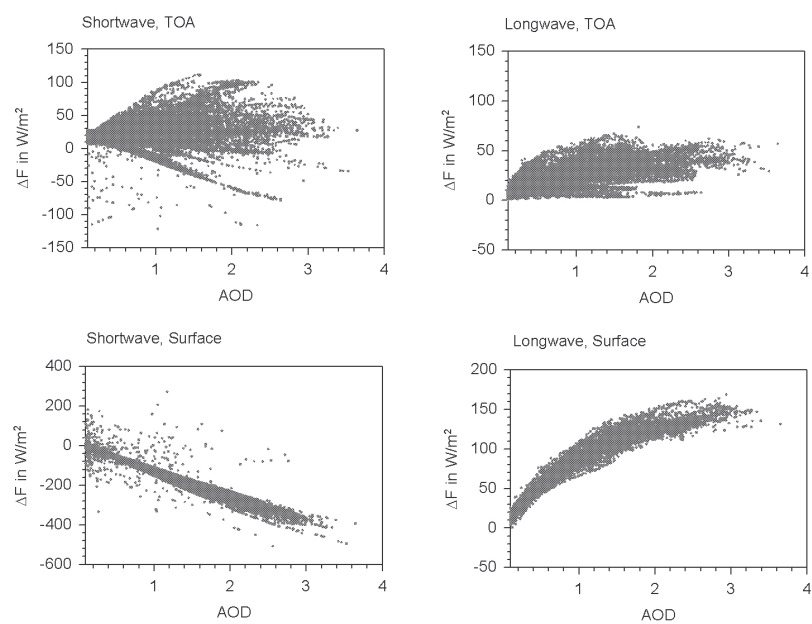

Fig. 9. Difference in shortwave and longwave radiation at the surface and TOA due to mineral dust particles at 7 March 2006, 8 March 2006 and 21 June 2007, 12:00 UTC (AOD at $450 \mathrm{~nm}$ ).

They determined a longwave dust forcing efficiency of $20.6 \mathrm{~W} \mathrm{~m}^{-2}$ at TOA. The maximum was $30.3 \mathrm{~W} \mathrm{~m}^{-2}$ and the minimum $13.8 \mathrm{~W} \mathrm{~m}^{-2}$. Close to the source areas the dust forcing efficiency was determined as $29 \mathrm{~W} \mathrm{~m}^{-2}$ by Helmert et al. (2007). For the dust outbreak in March 2006 Slingo et al. (2006) derived the outgoing longwave radiation from the GERB broadband radiometer. They show that the net longwave radiation at TOA increased by $30 \mathrm{~W} \mathrm{~m}^{-2}$. Mallet et al. (2009) found a positive effect of dust aerosols on net longwave radiation on TOA over the entire West Africa region during 9-12 March 2006 (at noon). They determined an increase between 20 and $50 \mathrm{~W} \mathrm{~m}^{-2}$.

The relationship of net longwave forcing and AOD at TOA at 12:00 UTC for our model results is not as pronounced as for net longwave fluxes at surface (Fig. 9). The mean increase for a dust layer with an AOD $(450 \mathrm{~nm})$ of 1 is $26 \mathrm{~W} \mathrm{~m}^{-2}$. The reduction of outgoing longwave radiation at TOA can be caused by a reduction in surface temperature due to the decrease of downward shortwave radiation or by the absorption and re-emission of longwave radiation by the dust plume.

\subsection{Effects on the temperature}

We will discuss an increase of the $2 \mathrm{~m}$ temperature during the day in more detail on the basis of the dust storm in March 2006. During this dust storm the dust particles were located in the boundary layer.

The energy available at the ground is reduced due to the reduction of the net incoming radiative flux during day. According to this the surface temperature should decrease. This is the case during the first simulation day. After $15 \mathrm{~h}$ simulation time, during afternoon on 5 March, the $2 \mathrm{~m}$ temperature decreases by $0.2 \mathrm{~K}$ to $3 \mathrm{~K}$ due to the dust plume (Fig. 10).
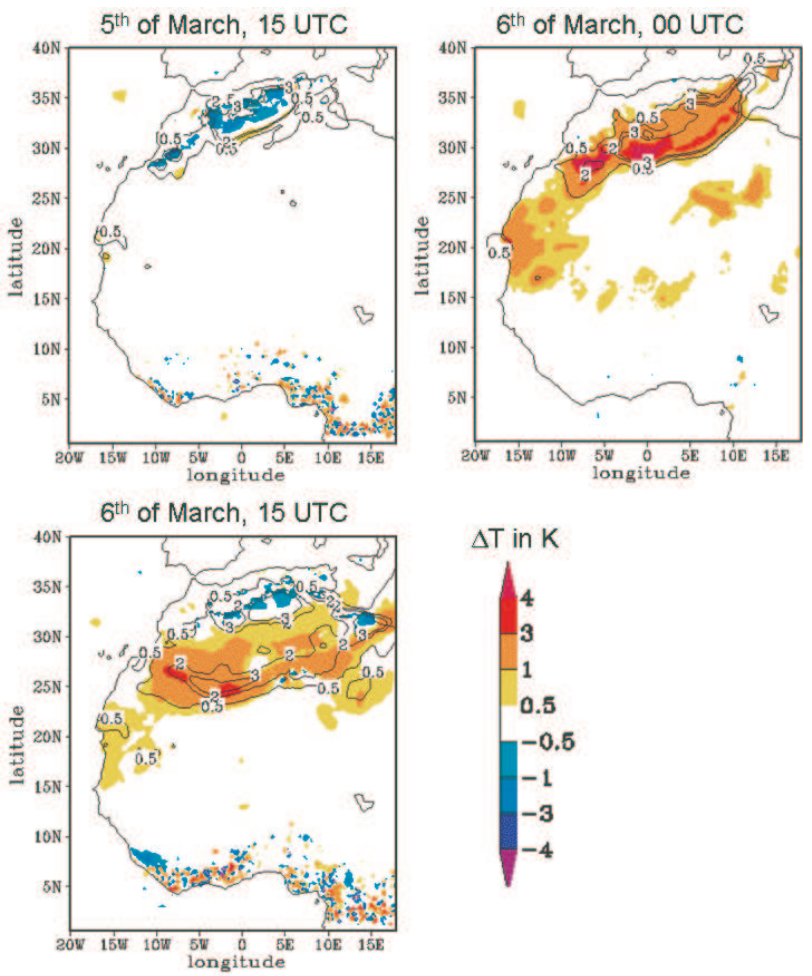

Fig. 10. Difference in $2 \mathrm{~m}$ temperature between runs $\mathrm{F}$ and CTRL and simulated AOD at $450 \mathrm{~nm}$ of run $\mathrm{F}$ (contour lines) during the dust outbreak in March 2006.

Changes in temperature in regions without dust particles, e.g. in the region of the Intertropical Convergence Zone, are due to changes in cloud cover. The maximum decrease in $2 \mathrm{~m}$ temperature is about $3 \mathrm{~K}$. Helmert et al. (2007) determined a reduction in $2 \mathrm{~m}$ temperature of $3 \mathrm{~K}$ for more reflecting particles and of $3.3 \mathrm{~K}$ for more absorbing particles close to source areas. Milton et al. (2008) determined a reduction in $1.5 \mathrm{~m}$ temperature between $0.5 \mathrm{~K}$ and $2 \mathrm{~K}$ for 8 March 2008. Tulet et al. (2008) found a reduction in surface temperature of more than $6 \mathrm{~K}$ in some places during the end of the dust storm in March 2006.

The $2 \mathrm{~m}$ temperature in run $\mathrm{F}$ is higher than in run CTRL during the night of 5-6 March (Fig. 10). The nocturnal cooling is reduced by up to $5 \mathrm{~K}$ in run F. Tegen et al. (2006) determined a reduction of nocturnal cooling of approximately $1 \mathrm{~K}$ due to a dust plume in the Bodélé Depression. Pérez et al. (2006) found a reduction in near surface temperature during both day and night.

During the next day the temperature in run $\mathrm{F}$ is higher than in run CTRL in areas that were influenced by the dust plume during the night before or which are affected by the advection of heated (by dust particles) air (Fig. 10). This is caused by a combination of reduction of nocturnal cooling and the warming of the air layer due to the absorption of radiation by the mineral dust particles. Due to the reduction of shortwave 

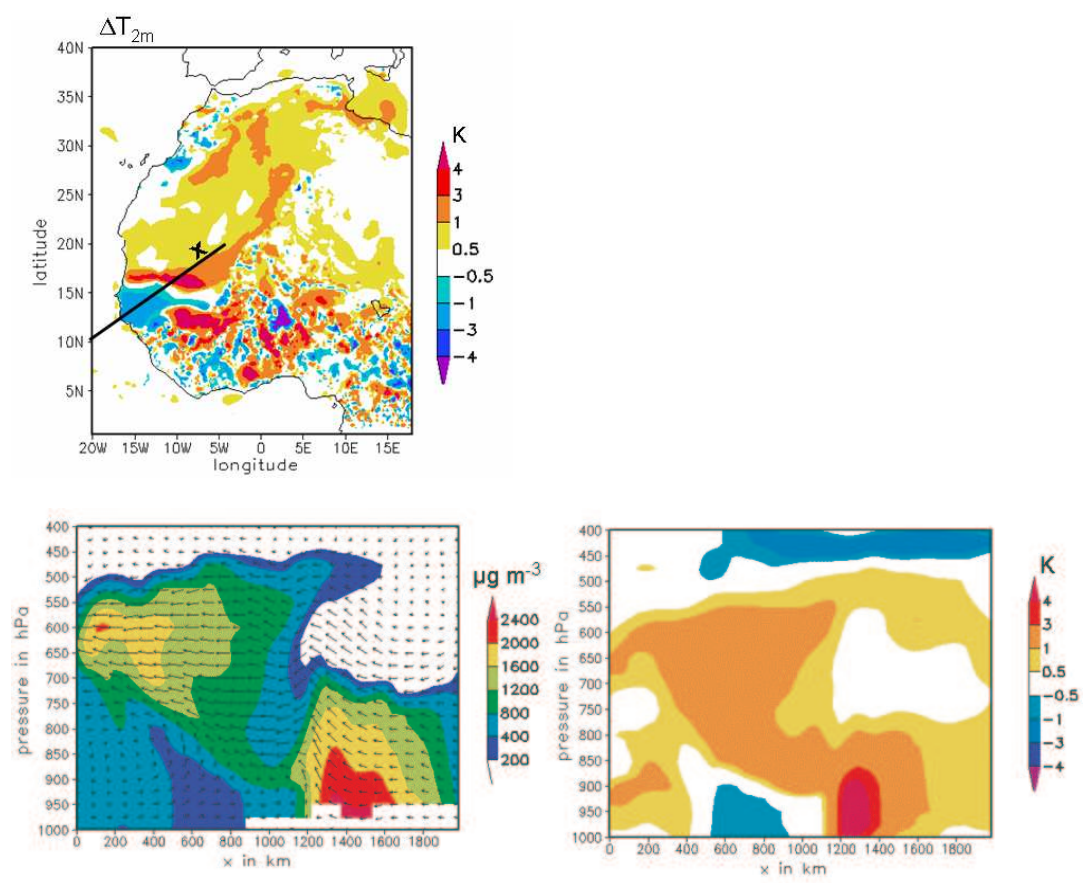

Fig. 11. Simulated difference in $2 \mathrm{~m}$ temperature in $\mathrm{K}$ between runs $\mathrm{F}$ and CTRL (top) and vertical cross section of mass concentration of mineral dust (bottom left) and difference in potential temperature (bottom right) along the line indicated by x on 21 June 2007, 15:00 UTC.

radiation at the surface the temperature difference during day is not as high as during night.

During the dust episode that occurred over West Africa in June 2007 the dust layer is elevated through isentropic lifting in the intertropical discontinuity zone (Stanelle, 2008). Figure 11 shows the $2 \mathrm{~m}$ temperature difference between run $\mathrm{F}$ and CTRL for 21 June 2007, 15:00 UTC. At the bottom of the same figure is shown a vertical cross section of the mass concentration of mineral dust and of the temperature difference along the line marked in Fig. 11, top. An increase in near surface temperature occurs in areas where the dust layer is located close to the surface as it was the case during the episode in March 2006. A decrease in near surface temperature is found in those areas where an elevated dust layer occurs. In this case the cooling is also reduced during night. The decrease in nocturnal cooling does not lead to an increase in near surface temperature during daytime in this case. The reduction of downward shortwave radiation during the day causes a decrease of the temperature in the boundary layer. The air layer which is heated by absorption of radiation by dust particles is above the boundary layer. This shows that the location and the vertical extension of the dust plume determine the effect on $2 \mathrm{~m}$ temperature.

Due to the different influence of an elevated and a near surface dust layer on the surface temperature during day, the meridional temperature gradient at the surface increases (Fig. 11). The North becomes warmer and the South colder due to the radiative effect of the dust layer. This increase in the meridional temperature gradient results in an intensi- fication of the secondary circulation in the region of the intertropical front (Stanelle, 2008). The upward motion is increased by a factor of 2 in run F in comparison to run CTRL on 21 June, 21:00 UTC.

\subsection{Changes of the emission rate of dust particles}

Changes in the state of the atmosphere induce modifications in the emission rate of dust particles. As discussed in Sect. 2.1 the emission of dust particles depend on the friction velocity and the soil properties. The soil properties are fixed in time but friction velocity alters due to changes in wind speed and thermal stability.

The regional averaged $\left(18^{\circ} \mathrm{W}-20^{\circ} \mathrm{E}, 12^{\circ} \mathrm{N}-35^{\circ} \mathrm{N}\right)$ wind velocity at $10 \mathrm{~m}$ above surface and the spatial integral of the emission dust flux during the dust events in March and June is shown in Fig. 12. The emission rate of dust particles has a diurnal cycle. The simulated emission rates reach their maximum around noon and their minimum around 22:00 UTC. Caused by the diurnal cycle of the friction velocity the simulated dust emission is low during night and high during day. At noon of 7 March 2006 the total emission rate in the model area reaches a maximum of more than $100 \mathrm{ts}^{-1}$. During night the total emission rate in run $\mathrm{F}$ is larger than in run CTRL by a factor of 2 . The thermal stability at the surface is reduced in run $\mathrm{F}$ in comparison to run CTRL during night. This reduction is induced by the decrease in nocturnal cooling due to the dust layer. During noon the mean wind velocity decreases slightly in run F. This results in a decrease of 

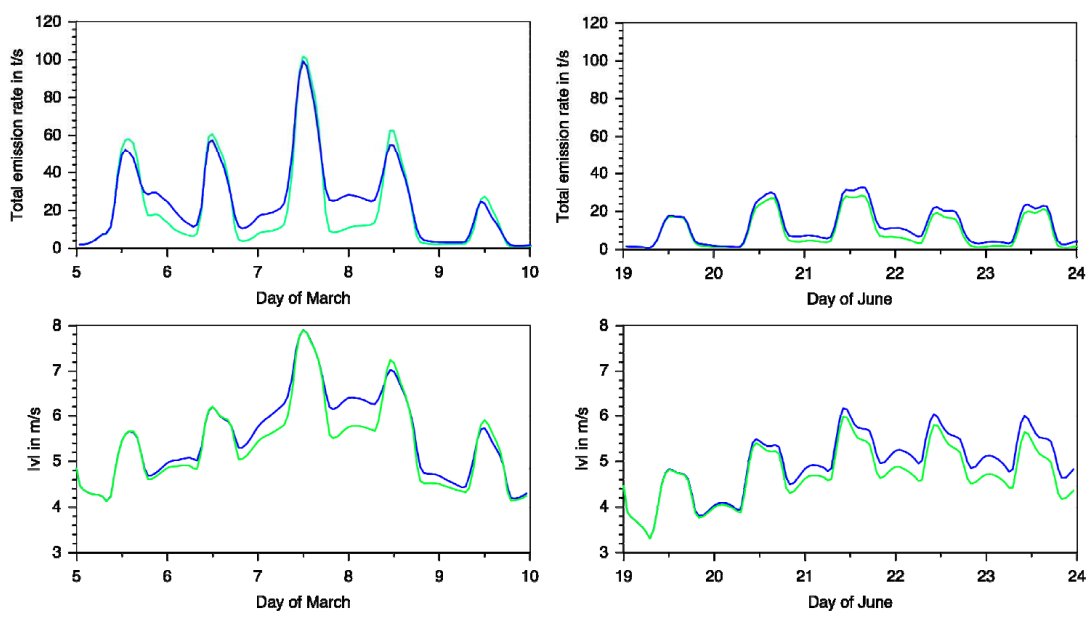

Fig. 12. Total emission rate of mineral dust particles in $t / \mathrm{s}$ (top) and the averaged absolute value of wind velocity at $10 \mathrm{~m}$ above surface (bottom) for the area $18^{\circ} \mathrm{W}-20^{\circ} \mathrm{E}, 12^{\circ} \mathrm{N}-35^{\circ} \mathrm{N}$ calculated by run F (blue) and CTRL (green) for the dust events in March 2006 (left) and June 2007 (right).

dust emission. Integrated over the entire simulation period (5-10 March) the total emission flux is about $16 \%$ higher in run $\mathrm{F}$ than in run CTRL.

During the dust event in March 2006 nearly entire West Africa is influenced by the dust storm. Only local dust storms took place during June 2007. Consequently the emission fluxes are much higher in March than in June, also if nearly the same mean wind velocity occurred (compare 6 March and 21 June).

21 June is the day with the most intensive total dust emission flux in the simulation area during the dust episode in June 2007. During that day the increase in dust emission in run $\mathrm{F}$ in comparison to run CTRL is between 12\% (noon) and $100 \%$ (during night). During the next two days the mean wind velocity is in the same order as during 21 June, but the emission flux decreases. This is due to the fact that the areas with highest wind speed during the 22 June and 23 June are situated in the south where only a few dust source areas are present. Integrated over the whole simulation period (19-24 June) and the simulation area the increase in dust emission is $25 \%$ when considering the feedback between dust particles and radiative fluxes.

Miller et al. (2004) determined in their global study a decrease of global dust emissions of $15 \%$ due to the direct aerosol effect of mineral dust particles. They neglected larger particles, which have particularly an influence of the longwave radiation. Especially close to source areas the neglecting of large particles can lead to an underestimation of dust emissions in a dust-radiation-feedback run. Heinold et al. (2007) found a decrease of 50\% in dust emission flux in Chad during noon when considering the feedback between dust particles and radiation. We found a much less decrease in emission flux in run F during noon in March and even an increase in June. There is a reduction in the sensible heat flux in most of the regions influenced by the dust particles in both of our feedback simulations (Stanelle, 2008). This reduction is also observed by Miller et al. (2004). During March 2006 the reduction results in a decrease of wind velocity and consequently in a decrease of dust emission. In June there is a small region around $17^{\circ} \mathrm{N}$ and $6^{\circ} \mathrm{W}$ where the sensible heat flux increases during noon, thus the wind velocity increases. In this area the dust emission flux is very high.

Changes in dust emission influence the concentration of dust particles in the atmosphere and hence the radiative fluxes. We showed changes in atmospheric state initialized by the direct aerosol effect of dust particles. These changes induce a vertical displacement of the dust particles, especially in the region of the ITF during the dust episode in June 2007. This modification also influences the radiative effect of dust particles, but the influence of changes in dust emission flux is higher. However, both facts lead to the conclusion that it is necessary to use online coupled dust-atmosphere model systems to calculate the influence of dust particles on radiative fluxes.

\section{Conclusions}

We extend the fully online coupled model system COSMOART (Vogel et al., 2009) to treat mineral dust particles and their influence on the radiative fluxes.

We compared our model results with observations for the dust event in March 2006. The location of the dust front was captured by our model, only at some stations the simulated dust front arrived a few hours later than the observed one. The comparison with measurements of radiative fluxes at Niamey show a reasonable agreement between modelled and observed radiative fluxes when the influence of dust particles on radiative fluxes is considered in the model run. The 
downward shortwave radiation at the surface is well reproduced by run $\mathrm{F}$ in Niamey. The downward longwave radiation at the surface increases after the passage of the dust front in both observation and run F. The rise in downward longwave radiation is overestimated in run F. After the passage of the dust front the observed diurnal temperature range is reduced. This is reproduced by the feedback run. The fact that even the model run without the consideration of the feedback between mineral dust particles and radiative fluxes reproduces the observed decrease in $2 \mathrm{~m}$ temperature after the arrival of the dust front shows that the initial decrease is caused by the passage of the cold front and not by the dust particles.

We analysed the radiative efficiency of dust particles. For shortwave radiation at the surface we found a radiative efficiency of $-140 \mathrm{~W} \mathrm{~m}^{-2}$. At TOA the influence of dust particles depends strongly on surface albedo. In this case we did not find a clear relationship between AOD and changes in net shortwave radiative fluxes. At the surface the increase of the net longwave radiative fluxes is about $79 \mathrm{~W} \mathrm{~m}^{-2}$ for a dust layer with an AOD of 1 . If such a dust layer is present the increase of net longwave radiative fluxes is approximately $26 \mathrm{~W} \mathrm{~m}^{-2}$ at TOA.

We found that mineral dust particles are able to cause both, a decrease and an increase in near surface temperature during the day. They cause a decrease in regions where dust particles are freshly emitted or an elevated dust layer is present. The decrease in $2 \mathrm{~m}$ temperature is up to $4 \mathrm{~K}$. The $2 \mathrm{~m}$ temperature increases if the dust layer is attached to the surface and is present at least since the day before. The increase is caused by a combination of the reduction of nocturnal cooling and the warming of the air layer due to the absorption of radiation by the mineral dust particles. Due to the reduction of shortwave radiation at the surface the temperature difference during day is not as high as during night.

The feedback between mineral dust particles and radiative fluxes leads to changes in the physical state of the atmosphere. Changes in the wind field and the thermal stability induce modifications in the emission flux of dust particles. We found an increase in the total emission flux of dust particles by about 16\% during the dust storm in March 2006 and $25 \%$ during the dust episode in June 2007. The main increase takes place during night. In wide areas the emission flux decreases slightly during the day. Our results demonstrate the importance to use online coupled models to determine the emission flux and the radiative effect of mineral dust particles.

Based on our model results we conclude that these processes should be included in numerical weather forecast models.

Acknowledgements. Based on a French initiative, AMMA was built by an international scientific group and is currently funded by a large number of agencies, especially from France, UK, US and Africa. It has been the beneficiary of a major financial contribution from the European Community's Sixth Framework Research Programme. Detailed information on scientific coordination and funding is available on the AMMA International web site http://www.amma-international.org. Acknowledgement is made for the use of ECMWF's computing and archive facilities through, the special project "Mesoscale modelling using the DWD COSMOModel". D. Tanré, P. Goloub und B. Chatenet allowed us to use their AERONET data. We thank Beatrice Marticorena for the detailed set of the surface data that was necessary to run our dust emission module.

Edited by: P. Formenti

\section{References}

Ackermann, A. S., Toon, O. B., Stevens, D. E., Heymsfield, A. J., Ramanathan, V., and Welton, E. J.: Reduction of tropical cloudiness by soot, Science, 288, 1042-1047, 2000.

Albrecht, B. A.: Aerosols, cloud microphysics, and fractional cloudiness, Science, 245, 1227-1230, 1989.

Alfaro, S. C. and Gomes, L.: Improving the large-scale modelling of the saltation flux of soil particles in presence of nonerodible elements, J. Geophys. Res., 100, 16357-16366, 1995

Alfaro, S. C. and Gomes, L., Modeling mineral aerosol production by wind erosion: Emission intensities and aerosol size distributions in source areas, J. Geophys. Res., 109, D08208, doi:10.1029/2000JD900339, 2001.

Bohren, C. F. and Huffman, D. R.: Absorption and Scattering of Light by Small Particles, John Wiley and Sons, New York, 1983.

Chaboureau, J.-P., Tulet, P., and Mari, C.: Diurnal cycle of dust and cirrus over West Africa as seen from Meteosat Second Generation satellite and a regional forecast model, Geophys. Res. Lett., 34, L02822, doi:10.1029/2006GL027771, 2007.

Callot Y., Marticorena, B., and Bergametti, G.: Geomorphologic approach for modelling the surface features of arid environments in a model of dust emissions: application to the Sahara desert, Geodinamica Acta, 13, 245-270, 2000.

Chameides, W. L., Lou, C., Saylor, R., Streets, D., Huang, Y., Bergin, M., Giorgi, F.: Correlation between model-calculated anthropogenic aerosols and satellite-derived cloud optical depth: Indication of indirect effect?, J. Geophys. Res., 107(D10), 4085, doi:10.1029/2000JD000208, 2002.

Charlson, R. J., Schwartz, S. E., Hales, J. M., Cess, R. D., Coakley, J. A., Hansen, J. E., and Hofmann, D. J.: Climate forcing by anthropogenic aerosols, Science, 255, 423-430, 1992.

Chen, S., Kuo, Y., Ming, W., and Ying, H.: The effect of dust radiative heating on low-level frontogenesis, J. Atmos. Sci., 52, 1414-1420, 1994.

Cook, J. and Highwood, E. J.: Climate response to tropospheric absorbing aerosols in an intermediate general-circulation model, Q. J. Roy. Meteorol. Soc., 130, 175-191, 2004.

European Centre for Medium-Range Weather Forecasts, IFS documentation, technical report, Reading, UK, available at: http: //www.ecmwf.int/research/ifsdocus/, 2004.

Fécan, F., Marticorena, B., and Bergametti, G.: Parametrization of the increase of the aeolian erosion threshold wind friction velocity due to soil moisture for arid and semi-arid areas, Ann. Geophys., 17, 149-157, doi:10.1007/s00585-999-0149-7, 1999.

Formenti, P., Rajot, J. L., Desboeufs, K., Chevaillier, S., Caquineau, S., Nava, S., Chiari, M., Triquet, S., Journet, E., Gau- 
dichet, A., Alfaro, S., Haywood, J., Coe, H., and Highwood, E.: Regional variability of the composition of mineral dust from western Africa: Results from the AMMA SOP0/DABAX and DODO field campaigns, J. Geophys. Res, 113, D00C13, doi:10.1029/2008JD009903, 2008.

Fouquart, Y., Bonnel, B., Brogniez, G., Buriez, J. C., Smith, L., Morcrette, J. J., and Cerf, A.: Observations of Saharan aerosols: Results of ECLATS field experiment. Part II: broadband radiative characteristics of aerosols and vertical radiative flux divergence, J. Clim. Appl. Meteorol., 26, 38-52, 1987.

Gillies, J. A., Nickling, W. G., and McTainsh, G. H.: Dust concentration and particle-size characteristics of an intense dust haze event: Inland delta region, Mali, West Africa, Atmos. Environ., 30, 1081-1090, 1996.

Gomes, L., Rajot, J. L., Alfaro, S. C., and Gaudichet, A.: Validation of a dust production model from measurements performed in semi-arid agricultural areas of Spain and Niger, Cantena, 57, 257-271, 2003.

Grams, C. M., Jones, S. C., Marsham, J. H., Parker, D. J., Haywood, J., and Heuveline, V.: The Atlantic Inflow to the Saharan heat low: Observations and Modelling, Q. J. Roy. Meteorol. Soc., 136(s1), 125-140, 2010.

Grini, A., Tulet, P., and Gomes, L.: Dusty weather forecasts using the MesoNH mesoscale atmospheric model, J. Geophys. Res., 111, D19205, doi:10.1029/2005JD007007, 2006.

Haywood, J. M., Allan, R. P., Culverwell, I., Slingo, T., Milton, S., Edwards, J., and Clerbaux, N.: Can desert dust explain the outgoing longwave radiation anomaly over the Sahara during July 2003?, J. Geophys. Res., 102, 6831-6864, 2005.

Heinold, B., Helmert, J., Hellmuth, O., Wolke, R., Ansmann, A., Marticorena, B., Laurent, B., and Tegen, I.: Regional modeling of Saharan dust events using LM-MUSCAT: Model description and case studies, J. Geophys. Res., 112, D11204, doi:10.1029/2006JD007443, 2007.

Helmert, J., Heinold, B., Tegen, I. Hellmuth, O., and Wendisch, M.: On the direct and semi-direct effect of Saharan dust over Europe: A case study, J. Geophys. Res., 112, D13208, doi:10.1029/2006JD007444, 2007.

IPCC, Climate Change 2007: The Physical Basis, in: Changes in Atmospheric Constituents and in Radiative Forcing, edited by: Forster, P., Ramaswamy, V., Artaxo, R., Berntsen, T. Betts, R., Fahey, D. W., Haywood, J., Lean, J., Lowe, D. C., Myhre, G., Nganga, J., Prinn, R., Raga, G., Schulz, M., and Van Dorland, R., Cambridge University Press, Cambridge, United Kingdom and New York, NY, USA, 2007.

Johnson, B. T., Shine, K. P., and Forster, P. M.: The semi-direct aerosol effect: Impact of absorbing aerosols on maritime stratocumulus, Q. J. Roy. Meteorol. Soc., 130, 1407-1422, 2004.

Karyampudi, V. M. and Carlson, T. N.: Analysis and numerical simulations of the Saharan air layer and its effects on easterly wave disturbances, J. Atmos. Sci., 45, 3102-3136, 1988.

Kassianov, S. I., Barnard, J. C., and Ackerman, T. P.: Retrieval of aerosol microphysical properties using surface Multi Filter Rotating Shadowband Radiometer (MFRSR) data: Modeling and observations, J. Geophys. Res., 110, D06208, doi:10.1029/2004JD005337, 2005.

Kischa, P., Alpert, P., Barkan, J., Kirchner, I., and Machenhauer, B.: Atmospheric response to Saharan dust deduced from ECMWF reanalysis (ERA) temperature increments, Tellus B, 55, 901-
913, 2003.

Knippertz, P. and Fink, A. H.: Synoptic and dynamic aspects of an extreme springtime Saharan dust outbreak, Q. J. Roy. Meteorol. Soc., 132, 1153-1177, 2006.

Lacis, A. A. and Mishchenko, M. I.: Climate forcing, climate sensitivity, and climate response: A radiative modelling perspective on atmospheric aerosols, in: Aerosol Forcing of Climate: Report of the Dahlem Workshop on Aerosol forcing of Climate, edited by: Charlson, R. and Heintzenberg, J., 11-42, John Wiley Sons. Chichester, England/New York, Berlin, 1995.

Liao, H. and Seinfeld, J. H.: Radiative forcing by mineral dust aerosols: sensitivity to key variables, J. Geophys. Res, 103, 31637-31645, doi:10.1029/1998JD200036, 1998.

Lu, H. and Shao, Y.: A new model for dust emission by saltation bombardment, J. Geophys. Res., 104, 16827-16841, 1999.

Mallet, M., Tulet, P., Serça, D., Solmon, F., Dubovik, O., Pelon, J., Pont, V., and Thouron, O.: Impact of dust aerosols on the radiative budget, surface heat fluxes, heating rate profiles and convective activity over West Africa during March 2006, Atmos. Chem. Phys., 9, 7143-7160, doi:10.5194/acp-9-7143-2009, 2009.

Marsham, J. H., Parker, D. J., Grams, C. M., Taylor, C. M., and Haywood, J. M.: Uplift of Saharan dust south of the intertropical discontinuity, J. Geophys. Res., 113, D21102, doi:10.1029/2008JD009844, 2008.

Marticorena B., Bergametti, G., Aumont, B., Callot, Y., N'Doumé, C., and Legrand, M.: Modeling the atmospheric dust cycle: 2Simulations of Saharan dust sources, J. Geophys. Res., 102, 4387-4404, 1997.

Messager C. J., Parker, D. J., Reitebuch, O., Agusti-Panareda, A. and Taylor, C. M.: Structure and dynamics of the Saharan heat low during the West African Monsoon 2006 onset: Observations and analyses, Q. J. Roy. Meteorol. Soc., 136, 107-124, 2009.

Miller, M. A. and Slingo, A.: The ARM Mobile Facility and its first international deployment: measuring radiative flux divergence in West Africa, B. Am. Meteorol. Soc., 88, 1229-1244, 2007.

Miller, R. L., Perlwitz, J., and Tegen, I.: Feedback upon dust emission by dust radiative forcing through the planetary boundary layer, J. Geophys. Res., 109, D24209, doi:10.1029/2004JD004912, 2004.

Milton, S. F., Greed, G., Brooks, M. E., Haywood, J., Johnson, B., Allan, R. P., and Grey, W. M. F.: Modelled and observed atmospheric radiation balance during West Africa dry season: Role of mineral dust, biomass burning aerosol, and surface albedo, J. Geophys. Res., 113, D00C02, doi:10.1029/2007JD009741, 2008.

Mishchenko, M. I., Travis, L. D., and Lacis, A. A.: Scattering, Absorption, and Emission of Light by Small Particles, Cambridge University Press, Cambridge, UK, 2002.

Myhre, G., Grini, A., Haywood, J. M., Stordal, F., Chatenet, B. C. B., Tanré, D., Sundet, J. K., Jostein, K., and Isaksen, I. S. A.: Modeling the radiative impact of mineral dust during the Saharan Dust Experiment (SHADE) campaign, J. Geophys. Res, 108(D18), 8579, doi:10.1029/2002JD002566, 2003.

Nenes, A., Contant, W. C., and Seinfeld, J. H.: Black carbon radiative heating effects on cloud microphysics and implications for the aerosol indirect effect-2. cloud microphysics, J Geophys. Res., 107(D21), 4605, doi:10.1029/2002JD002101, 2002.

Nickovic, S., Kallos, G., Papadopoulos, A., and Kakaliagou, O.: A model for prediction of desert dust cycle in the atmosphere, $\mathrm{J}$. 
Geophys. Res., 106, 18113-18129, 2001.

Patterson, E. M., Gillette, D. A., and Stockton, B. H.: Complex Index of Refraction between 300 and $700 \mathrm{~nm}$ for Saharan Aerosols, J. Geophys. Res., 82, 3153-3160, 1977

Pérez, C., Nickovic, S., Pejanovic, G., Baldasano, J. M., Özsoy, E.: Interactive dust-radiation modeling: A step to improve weather forecasts, J. Geophys. Res., 111, D16206, doi:10.1029/2005JD006717, 2006.

Perlwitz, J., Tegen, I., and Miller, R. L.: Interactive soil dust aerosol model in the GISS GCM 1. Sensitivity of the soil dust cycle to radiative properties of soil dust aerosols, J. Geophys. Res., 106, 18167-18192, 2001

Petzold, A., Rasp, K., Weinzierl, B., Esselborn, M., Hamburger, T., Dörnbrack, A., Kandler, K., Schütz, L., Knippertz, P., Fiebig, M., and Virkkula, A.: Saharan dust absorption and refractive index and from aircraft-based observations during SAMUM 2006, Tellus B, 61B, 118-130, 2009.

Redelsperger, J. L., Thorncroft, C. D., Diedhiou, A., Lebel, T., Parker, D. J., and Polcher, J.: African Multidisciplinary Analysis An International Research Project and Field Campaign, American Meteorological Society, 1739-1746, 2006.

Ritter, B. and Geleyn, J.-F.: A Comprehensive Radiation Scheme for Numerical Weather Prediction Models with Potential Applications in Climate Simulations, Mon. Weather Rev., 120, $303-$ 325, 1992.

Rosenfeld, D.: Suppression of rain and snow by urban and industrial air pollution, Science, 287, 1793-1796, 2000.

Schwartz, S. E.: The whitehouse effect - shortwave radiative forcing of climate by anthropogenic aerosols: An overview, J. Aerosol Science, 27, 359-382, 1996.

Seinfeld, J. H. and Pandis, S.: Atmospheric Chemistry and Physics., John Wiley \& Sons, Inc., 1998.

Shettle, E. P. and Fenn, R. W.: Models for Aerosols of the Lower Atmosphere and the Effects of Humidity Variations on Their Optical Properties, AFGL-TR-79-0214, 12, ADA085951, 1979.

Sinyuk, A., Torres, O., and Dubovik, O.: Combined use of satellite and surface observations to infer the imaginary part of refractive index of Saharan dust, Geophys. Res. Lett., 30, 1081, doi:10.1029/2002GL016189, 2003.

Slingo, A., Ackerman, T. P., Allan, R. P., Kassianov, E. I., McFarlane, S. A., Robinson, G. J., Barnard, J. C., Miller, M. A., Harries, J. E., Russell, J. E., and Dewitte, S.: Observations of the impact of a major dust storm on the atmospheric radiation balance, Geophys. Res. Lett., 33(24), L24817, doi:10.1029/2006GL027869, 2006.

Sokolik, I. N. and Toon, O. B.: Direct radiative forcing by anthropogenic airborne mineral aerosols, Nature, 381, 681-683, 1996.

Sokolik, I. N. and Toon, O. B.: Incorporation of mineralogical composition into models of the radiative properties of mineral aerosol from uv to ir wavelength, J. Geophys. Res., 104, 9423-9444, 1999.

Stanelle, T.: Wechselwirkungen von Mineralstaubpartikeln mit thermodynamischen und dynamischen Prozessen in der Atmosphäre über Westafrika, Dissertation, Institut für Meteorologie und Klimaforschung der Universität Karlsruhe, 157 pp., 2008.

Steppeler, J., Doms, G., Schättler, U., Bitzer, H., Gassmann, A., Damrath, U., and Gregoric, G.: Meso gamma scale forecasts using the nonhydrostatic model LM, Meteorol. Atmos. Phys., 82, 75-96, 2002.
Tanre, D., Geleyn, J.-F., and Slingo, J. M.: First results of the introduction of an advanced aerosol-radiation interaction in the ECMWF low resolution global model, In Proc. Of the Meeting of Experts on Aerosol and Their Climatic Effects, VA, WMO and International Association of Meteorology and Atmospheric Physics, 133-177, Williamsburg, 1984.

Tegen, I., Lacis, A. A., and Fung, I.: The influence on climate forcing of mineral aerosols from disturbed soils, Nature, 380, 419422, 1996.

Tegen, I., Harrison, S. P., Kohfeld, K., Prentice, I. C., Coe, M., and Heimann, M.: Impact of vegetation and preferential source areas on global dust aerosol: Results from a model study, J. Geophys. Res., 107(D21), 4576, doi:10.1029/2001JD000963, 2002.

Tegen, I., Heinold, B., Todd, M., Helmert, J., Washington, R., and Dubovik, O.: Modelling soil dust aerosol in the Bodélé depression during the BoDEx campaign, Atmos. Chem. Phys., 6, 43454359, doi:10.5194/acp-6-4345-2006, 2006.

Tompkins, A. M., Cardinali, C., Morcrette, J.-J., and Rodwell, M.: Influence of aerosol climatology on forecasts of the African Easterly Jet, Geophys. Res. Lett., 32, L10801, doi:10.1029/2004GL022189, 2005.

Tulet, P., Mallet, M., Pont, V., Pelon, J., and Boone, A.: The 713 March 2006 dust storm over West Africa: Generation, transport, and vertical stratification, J. Geophys. Res., 113, D00C08, doi:10.1029/2008JD009871, 2008.

Twomey, S. A., Piepgrass, M., and Wolfe, T. L.: An assessment if the impact of pollution on global cloud albedo, Tellus, Ser. B, 36, 356-366, 1984.

Vogel, B., Hoose, C., Vogel, H., and Kottmeier, C.: A Model of dust transport applied to the Dead Sea Area, Meteorol. Z., 6, 611-624, 2006.

Vogel, B., Vogel, H., Bäumer, D., Bangert, M., Lundgren, K., Rinke, R., and Stanelle, T.: The comprehensive model system COSMO-ART - Radiative impact of aerosol on the state of the atmosphere on the regional scale, Atmos. Chem. Phys., 9, 86618680, doi:10.5194/acp-9-8661-2009, 2009.

Volz, F. E.: Infrared Absorption of Atmospheric Aerosol Substances, J. Geophys. Res., 77, 1017-1031, 1972a.

Volz, F. E.: Infrared Refractive Index of Atmospheric Aerosol Substances, Applied Optics, 11, 755-759, 1972b.

Volz, F. E.: Infrared Optical Constants of Ammonium Sulfate, Saharan Dust, Volcanic Pumice, and Flyash, Applied Optics, 12, 564-568, 1973.

White, B. R., Soil transport by winds on Mars, J. Geophys. Res., 84, 4643-4651, 1979.

Woodward, S.: Modeling the atmospheric life cycle and radiative impact of mineral dust in the Hadley Centre climate model, J. Geophys. Res., 106, 18155-18166, 2001.

Yoshioka, M., Mahowald, N. M., Conley, A. J., Collins, W. D., Fillmore, D. W., Zender, C. S., and Coleman, D. B.: Impact of Desert Dust Radiative Forcing on Sahel Precipitation: Relative Importance of Dust Compared to Sea Surface Temperature Variations, Vegetation Changes, and Greenhouse Gas Warming, J. Clim., 20, 1445-1467, doi:10.1175/JCLI4056.1, 2007.

Zender, C. S., Bian, H., and Newman, D.: Mineral dust Entrainment and Deposition (DEAD) model: Description and 1990s dust climatotlogy, J. Geophys. Res., 108(D14), 4416, doi:10.1029/2002JD002775, 2003. 